\title{
Five Lessons from COVID-19 for Advancing Climate Change Mitigation
}

\author{
David Klenert $^{1}$ (D) Franziska Funke ${ }^{2,3} \cdot$ Linus Mattauch $^{2,4} \cdot$ Brian O'Callaghan $^{3}$
}

Accepted: 3 July 2020 / Published online: 3 August 2020

(c) Springer Nature B.V. 2020

\begin{abstract}
The nexus of COVID-19 and climate change has so far brought attention to short-term greenhouse gas (GHG) emissions reductions, public health responses, and clean recovery stimulus packages. We take a more holistic approach, making five broad comparisons between the crises with five associated lessons for climate change mitigation policy. First, delay is costly. Second, policy design must overcome biases to human judgment. Third, inequality can be exacerbated without timely action. Fourth, global problems require multiple forms of international cooperation. Fifth, transparency of normative positions is needed to navigate value judgments at the science-policy interface. Learning from policy challenges during the COVID-19 crisis could enhance efforts to reduce GHG emissions and prepare humanity for future crises.
\end{abstract}

Keywords COVID-19 · Climate change $\cdot$ Climate policy $\cdot$ Public support · Psychological bias $\cdot$ Inequality $\cdot$ Role of scientists $\cdot$ Global cooperation

\section{Introduction}

Increasing anthropogenic influence on the natural environment over many centuries (Goudie 2018) has led to significant global challenges at the nexus of planetary and human health, of which COVID-19 may just be the latest manifestation. ${ }^{1}$ Although the COVID-19

1 Climate change and a surge in zoonose pandemics such as COVID-19 both result from human interference with natural environments (Settele et al. 2020). In fact, the occurrence of new pathogens such as

The views expressed are purely those of the authors and may not in any circumstances be regarded as stating an official position of the European Commission.

David Klenert

david.klenert@ec.europa.eu

1 Joint Research Centre, European Commission, Calle Inca Garcilaso, 3, 41092 Seville, Spain

2 Institute for New Economic Thinking, Oxford Martin School, University of Oxford, Oxford, UK

3 Smith School of Enterprise and the Environment, School of Geography and the Environment, University of Oxford, Oxford, UK

4 Environmental Change Institute, School of Geography and the Environment, University of Oxford, Oxford, UK 
crisis is distinct in contemporary history in bringing simultaneous global health and economic impacts, it shares marked similarities with the climate crisis. The pandemic and climate change both present potentially devastating global problems with need for rapid remediating government intervention. This intervention, while inevitably creating losers, in both cases must be decisive and build on societal consensus.

The global economic consequences of COVID-19 will be dramatic. At the time of writing, the IMF (2020a) predicts that global GDP will contract by $4.9 \%$ in 2020, far greater than during the 2008-2009 Global Financial Crisis, while the European Commission (2020a) expects an even larger reduction of $8 \%$ for the Euro Area. Present policy debate connecting climate change and COVID-19 primarily concerns minimising these economic damages using clean recovery stimulus packages (Barbier 2020; Engström et al. 2020; Gawel and Lehmann 2020; Hepburn et al. 2020; Koundouri 2020; Lahcen et al. 2020; Rosenbloom and Markard 2020). ${ }^{2}$ However, the value of side-by-side COVID-19 and climate dialogues extends well beyond short- and medium-term fiscal policy (Helm 2020). The crises face similar challenges in addressing institutional and societal barriers against effective action. Learning from policy actions during the COVID-19 crisis could enhance efforts in fighting global climate change, as well as preparing humanity for future crises.

We draw five policy lessons from the early stages of the pandemic. First, delay is costly, but early and determined action is politically difficult. Second, broad public support is critical for early action and underestimating damages impacts support. Third, inequality can be exacerbated both by the threat itself and by mitigation policies, thus placing an additional constraint on policy making. Fourth, global problems require multiple forms of international cooperation and solidarity. Fifth, transparency of normative standpoints and effective communication strategies for inoculating citizens against misinformation are needed to navigate value judgments at the science-policy interface.

For each lesson, we outline commonalities between COVID-19 and climate change that complicate effective mitigation in both cases. We precipitate conclusions for effective climate policy design based on the challenges faced by global governments during the pandemic. As policy reactions to COVID-19 are, in most cases, not directly translatable to the context of climate change, we highlight corresponding findings from existing research in climate policy. ${ }^{3}$ The lessons covered in this piece reflect assumed long-run importance for the future of climate policy. Between lessons two, three and four, we gradually move from the micro to the macro level, by going from individual support among the citizenry, to community-wide distribution of resources and burdens, to international collaboration. While we choose to retain a close focus on climate change mitigation, it may be a worthwhile exercise for future research to extend the analysis to adaptation or discern additional adaptation-specific lessons from COVID-19 (Herrero and Thornton 2020).

While COVID-19 demonstrates that, in a globalised world, infectious disease can bear striking similarities to known global commons problems, a marked difference is

Footnote 1 (continued)

Ebola, HIV, Marburg or SARS seems to have sped up in recent years as a consequence of human expansion into remote ecosystems (Johnson et al. 2020).

2 A related discussion concerns a reduction in GHG emissions that resulted from the pandemic and its economic consequences: Le Quéré et al. (2020), for instance, estimate that by mid-April 2020, daily global $\mathrm{CO}_{2}$ emissions are on average $17 \%$ below their mean 2019 levels.

3 For example, while lockdowns have been a successful mitigation strategy against the spread of COVID19 (c.f. Hsiang et al. 2020; Flaxman et al. 2020), the measure as such does not seem to teach us much about effective policy responses to climate change. What we can learn from the implementation of lockdowns is that this measure was only politically feasible once policymakers and the public were alerted to the threat of COVID-19 and perceived it as grave enough to warrant strict limitations on their liberties. 
that climate change mitigation necessarily relies on much more anticipatory and global responses. In economic terms, both issues have been characterized as "global public bads" (Fuentes et al. 2020). One characteristic of COVID-19, and epidemics more generally, however, is that there are at least limited opportunities for exclusion, as countries or regions can shield themselves from a virus through localized mitigation. Infectious disease can therefore not be treated as a "pure public bad", but also bears some traits of a "club bad". Unlike the climate crisis, epidemiological challenges create much stronger incentives for localized mitigation and immunization and unfold over shorter timescales.

On balance, this article provides evidence that climate change is more difficult to confront than the current pandemic in many ways but that there is potential for lessons to be learnt from new approaches in a post-COVID era. This article integrates perspectives from environmental economics, behavioural and political science, and philosophy of public policy to draw lessons from COVID-19 and articulate a forward pathway for future climate policy proposals and their communication.

\section{Lesson 1: Delay is Costly, So Make Mitigation a Priority, Now}

The current pandemic shows that political leaders have a tendency to react slowly in the face of unprecedented threats. Few countries reacted quickly and slowed the progress of SARS-CoV-2 in its early stages: while Hong Kong, South Korea, Singapore and Taiwan drew from experience with epidemics in recent decades, some countries without this experience such as Czechia or Greece also managed to slow the progress of the virus early on. ${ }^{4}$ A majority of countries, especially those lacking recent experience with viral outbreaks, acted decisively only after local virus transmission had occurred and a large number of cases were reported, despite evidence of the gravity of the situation from other countries. ${ }^{5}$ On 2 March the European Centre for Disease Prevention and Control released recommendations to cancel mass gatherings in countries with locally transmitted cases (ECDC 2020) and the World Health Organization declared the coronavirus outbreak officially a pandemic on 11 March (WHO 2020a). However, in the first 2 weeks of March, there were still a large number of mass gatherings in many European countries, including soccer matches and demonstrations. Even after witnessing the dynamics of the pandemic in China and Europe, there was a delay in the introduction of nationwide measures such as school closures and social distancing guidelines in the US, which were eventually implemented on March 16 (New York Times 2020a). At the time of writing, the US is the country with the highest number of confirmed COVID-19 cases as well as deaths worldwide.

Delays in containment measures during global crises are all the more tragic as earlier action reduces costs and damages dramatically. In the case of COVID-19, acting early has made the difference between a prolonged full-scale lockdown and a high number of casualties, and much less dramatic measures such increased health screening at borders, contact tracing, public information campaigns and almost business-as-usual as for example in Taiwan (see Wang et al. 2020). In the early stages of the pandemic, it has been estimated that delaying some form of lockdown by a single day increases the numbers of cumulative cases

\footnotetext{
4 Although these countries avoided overwhelmed health care systems and, in some cases, complete economic shutdowns due to early action, the pandemic is still ongoing and case numbers change on a daily basis.

5 Bowles and Carlin (2020) stress that solutions to the pandemic were facilitated in many cases by virtuous responses from civil society, with implications for mitigating negative impacts on economic productivity.
} 


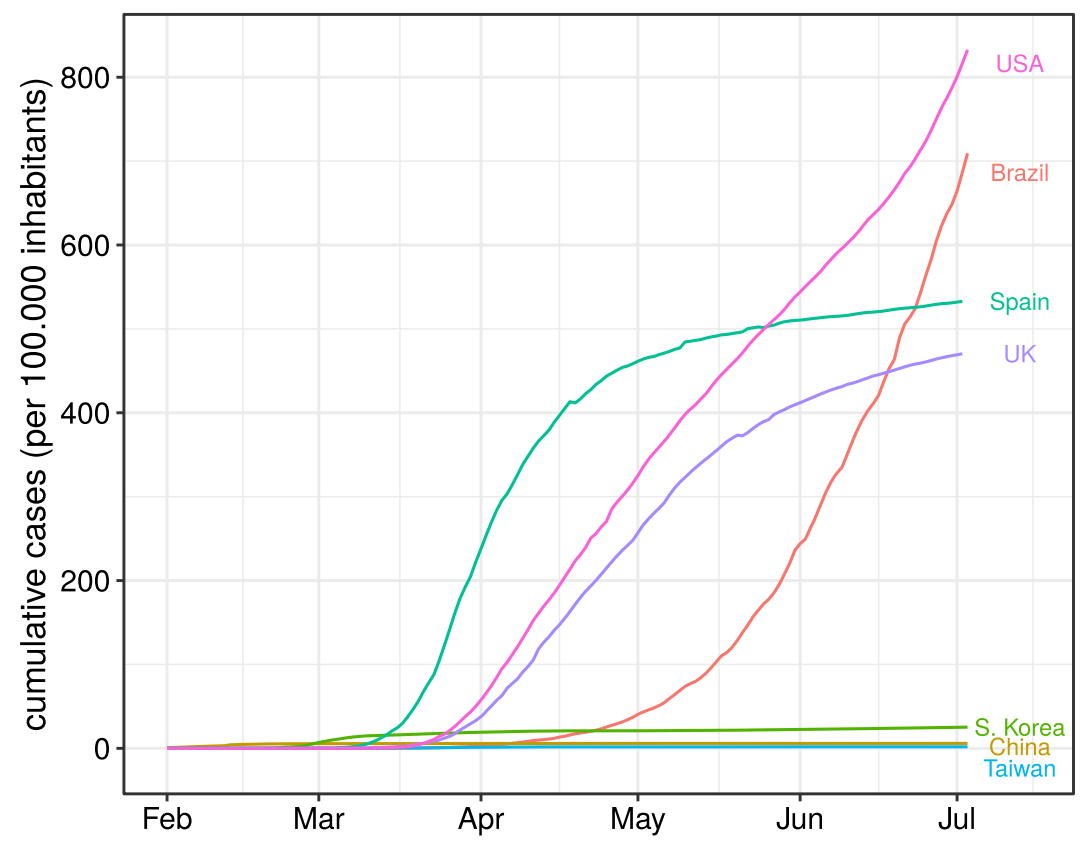

Fig. 1 COVID-19 cases per 100.000 inhabitants. Source: Own calculations based on data from the European Centre for Disease Prevention and Control https://www.ecdc.europa.eu/

by $40 \%$ (Pueyo 2020). For the United States, Pei et al. (2020) estimate that starting social distancing 1 week earlier could have avoided 55\% of deaths $(36,000)$ between mid-March and early May. Once a lockdown is implemented after a delay, it has to be maintained for longer, increasing not only casualties but also economic losses. Figure 1 compares the evolution of COVID-19 cases per capita in different countries.

On much longer time scales, decisions on climate policy also need to account for the fact that delay is very costly. Earlier action might reduce mitigation costs significantly (Dietz and Venmans 2019; Goulder 2020): The latest report of the Intergovernmental Panel on Climate Change (IPCC 2018) stresses the importance of limiting global warming to $1.5^{\circ} \mathrm{C}$ instead of $2{ }^{\circ} \mathrm{C}$ by the end of this century to avoid tipping points and irreversible changes in our environment. It highlights, in particular, that delayed climate action implies significantly higher costs, as it locks economies into carbon-intensive infrastructure, reduces flexibility in future response options and increases uneven distributional impacts between countries. More specifically, a meta study of 16 Integrated Assessment Models shows that delaying climate action by 10 years increases the cost of later climate action by 37\% (Furman et al. 2015). In a similar vein, a 2012 model comparison study estimates that delaying climate policy compatible with 2 degrees warming by the end of this century until 2020 would increase mitigation costs by around 50\% (Jakob et al. 2012).

The effects of climate change that are currently experienced, such as climate changerelated extreme weather events, wildfires and sea level rise, are only mild harbingers of projected future climate damages (IPCC 2014a). The political reaction to the COVID-19 pandemic suggests that societies have a tendency to take action too late in the face of a looming crisis, despite witnessing signs of escalation. Moreover, they take too long to 
actually implement policies. Ideally, the current crisis would make decision-makers and institutions aware of the immense costs of delaying climate actions and increase their responsiveness to climate change, similar to how countries with recent experience with viral outbreaks had a better responsiveness to COVID-19. However, even when policymakers are alerted to the urgency of climate change mitigation, decision-making in the context of climate change is further complicated by political economy constraints, in particular the efforts from industry lobbyists to delay or weaken emission reductions. While an economic shutdown to counter COVID-19 entails severe demand reductions and ensuing difficulties for industries in the short-term, a net-zero emissions reductions pathway necessitates permanent transformations away from fossil-fuel intensive production and consumption. Hence, vested corporate interests in the continuation of fossil-based business models will likely remain a persistent obstacle for increased climate action. In addition, early action is not popular if citizens are not convinced of the severity of the consequences (see Lesson 2). Conversely, if early policy responses are very effective, they can be perceived as an overreaction in hindsight, which may disincentivize politicians to implement anticipatory measures, especially when they have high costs. ${ }^{6}$ To the extent that policy-making is constrained by public opinion, behavioral biases among the citizenry might therefore further aggravate the problem of delay, as we discuss in the next section.

As a concrete strategy for strengthening incentives in favour of decisive and timely action, societies can delegate responsibility to institutions that are more closely aligned with long-term policy goals rather than short-term political interests. For example, if an undue focus on the immediate future in policy making is a major obstacle to advancing climate change mitigation, societies could agree to delegate responsibility for delivering emission reduction to carbon central banks, by analogy to the role of central banks for monetary policy (Helm, Hepburn and Mash 2003; Grosjean et al. 2016). A milder form of delegating such responsibility could be to create independent expert bodies with a mandate to recommend policy action to the government and stimulate related public debate, as pioneered by the United Kingdom and its Committee on Climate Change (Averchenkova et al. 2018).

In sum, decades of research and policy development mean that policy makers are starting from a much higher knowledge base and have years of experience to build on. The COVID-19 pandemic also illustrates that countries can adopt policies pioneered by frontrunners, once they turn out to be successful. As the spread of the virus aggravated, many countries eventually converged to similar policy responses: social distancing. ${ }^{7}$ Similarly, there are climate policy pioneers: countries which introduced high carbon prices (e.g. Sweden and Switzerland) or other policies through which they dramatically lowered their carbon footprint (coal phase-outs, climate legislation, low-carbon technology subsidies). Policy makers can look towards these countries to find inspiration for suitable policy responses and adapt them to local circumstances. International institutions as platforms for technical dialogue and knowledge exchange remain important for facilitating the dissemination of best practices around the world (see Lesson 4).

\footnotetext{
6 This may be due to omission bias (Baron and Ritov 2004), which leads people to prefer harms caused by omissions over equal or smaller harms caused by acts.

7 Proposals to let the virus spread to attain herd immunity were, in most cases, abandoned in the early stages after Ferguson et al. (2020) estimated the number of casualties of such a policy to be in the order of 250,000 in the UK and to exceed one million in the US.
} 


\section{Lesson 2: Find Ways to Get Citizens on Board}

In the early phases of the pandemic, a lockdown of the economy as implemented in the Chinese province of Wuhan would have seemed unimaginable to most nations outside of East Asia. Indeed, most countries hesitated to introduce strict and unpopular measures to stop the pandemic early on, in particular if they lacked previous experience with epidemics. Public support for specific measures to stop the spread of the virus increased when citizens perceived the threat as severe or imminent enough (for the United States see Ipsos 2020). Whether strict measures to mitigate pandemics or climate change are practically available to policymakers depends at least in part on public perception of the severity of these threats.

There are several effects at play that influence how people perceive and respond to different threats. First, the human brain has difficulties understanding non-linear dynamics (de Langhe et al. 2017), in particular exponential growth (Levy and Tasoff 2017). The spread of pandemics like COVID-19 is governed by exponential growth processes. This bias lets the pandemic appear unimpressive in its early stages, which causes delays in this phase.

Second, whether a threat is perceived as "imminent" changes reactions to it dramatically: As SARS-CoV-2 has spread globally and has received excessive media coverage, the threat of dying from the virus is more salient. COVID-19 is perceived as a particularly bad way of dying in the sense that people have little control over contracting the disease and the way it proceeds, as well as being a painful and relatively long process (Draulans 2020). Society is willing to pay relatively more to avoid such "bad deaths" in general (Sunstein 1997). COVID-19 exemplifies this as societies are paying a high price to avoid the threats of the pandemic, both financially and in terms of restrictions such as lockdowns. Moral psychologists have found that political judgment is largely driven by moral intuitions, not rational deliberation (Haidt 2001, 2007). It is therefore well substantiated that intuitive perceptions, such as concerning the imminence of a threat, matter for political responses.

Third, when people need to decide under uncertainty whether to respond to a threat, they rely on certain heuristics (Tversky and Kahneman 1974). While this is often an effective strategy, it might lead to biased outcomes. When assessing the probability of a pandemic in their region, humans rely on their own past experiences and determine the probability by the ease with which similar past events come to mind. This effect is called availability heuristic (Tversky and Kahneman 1973) and leads to an underestimation of the dangers of a COVID-19 pandemic in the early stages in countries without experience of pandemics in recent decades and hence to a lack of support for policy measures and to slow policy action.

In the case of climate change, similar mechanisms are at work that make its danger to human well-being difficult to grasp. It has been shown that the relationship between warming and damages is non-linear, due to tipping points and feedback effects in the system (Burke et al. 2015; Lenton 2020). This makes the dynamics of climate change especially hard to grasp and leads to an underappreciation of goals like limiting warming to $1.5{ }^{\circ} \mathrm{C}$. Regarding the perceived imminence of the threat, climate change gives the illusion that it could be controlled to some extent, and that it does not impact one's life in an immediate way. Judging from respective societal responses, dying from SARS-CoV-2 is apparently worse than dying from consequences of environmental pollution: an outcome that can hardly be justified from moral principles (Sunstein 1997).

Whether or not this is the case, from a perspective of moral judgement, the perceived properties of climate change make it difficult to raise the awareness it deserves and to take 


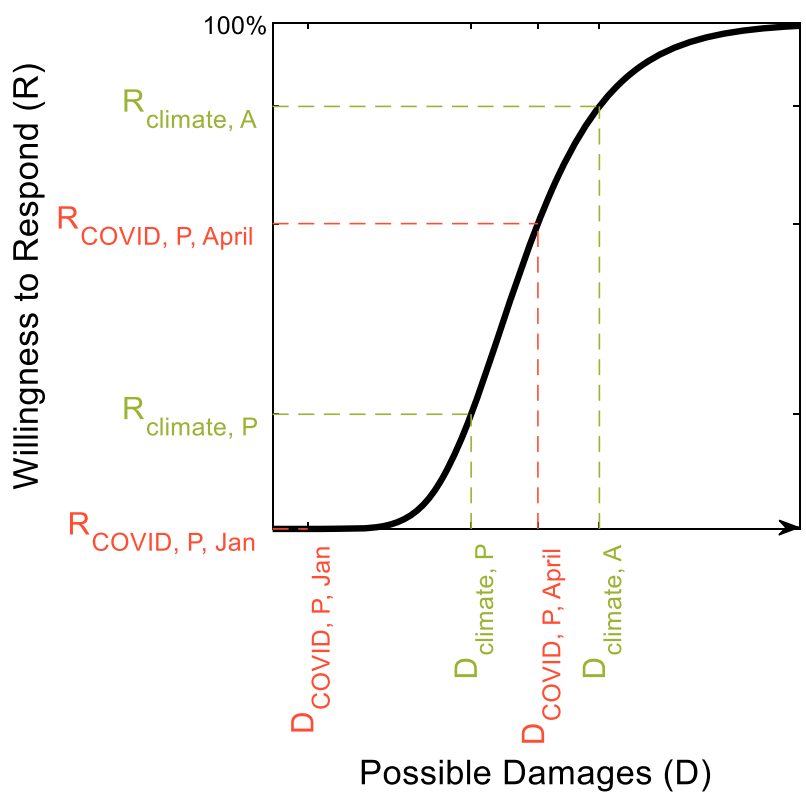

Fig. 2 Conceptual damage-response curve. Actual severity of possible societal climate damages $D_{\text {climate, } \mathrm{A}}$ are significantly greater than perceived severity $\mathrm{D}_{\text {climate,P. }}$. Actual damages are likely to increase over time due to inadequate intervention (not shown). Perceived (and actual) damages of COVID-19 in April 2020 $\mathrm{D}_{\text {COVID,P,April }}$ are greater than perceived damages in January $2020 \mathrm{D}_{\text {COVID,PJan }}$ where for most of the world perceived possible damages were below the level required to prompt meaningful intervention. Upward shift in perceived damages was due to more complete information, as well as higher perceived imminence of the threat, while upward shift in actual damages (not shown) was due to inaction. Logistic model curvature assumption is purely conceptual. Understanding curvature characteristics reflects opportunity for future work

early action. Markowitz and Shariff (2012) emphasise six main challenges from climate change to the human moral judgement system: (1) abstractness and cognitive complexity; (2) blamelessness of unintentional action; (3) provocation of self-defensive biases; (4) uncertainty leading to wishful thinking; (5) tribalism; (6) long time horizons and faraway places. There is reason to believe that the first four factors apply to COVID-19: van Bavel et al. (2020) note especially the uncertainty whether social interaction will actually lead to infections as a factor that reduces individuals' motivation to act altruistically. However, with regards to (5), tribal politics on pandemic responses seems so far limited to a few highly polarised countries (see also end of Lesson 4) and (6) does not apply. This makes climate change a more abstract threat compared to COVID-19.

The perception of threats has implications for policy-making. Depending on the nature of the threat, personal liberties are perceived differently. On the one hand, once disaster strikes, most citizens are generally collaborative and accept harsh limitations on their freedoms, at least temporarily, as seen with confinement measures to counter the spread of COVID-19. On the other hand, citizens are less willing to accept very minor limitations on their liberties, such as higher taxes on fuel, meat or air travel, when the threat does not appear imminent. Figure 2 is a simple illustration of the potential relationship between the perceived consequences of a threat and society's willingness to respond to it. In sum, we suggest that the same psychological biases (regarding 
non-linear dynamics, the perceived imminence of a threat and availability heuristics) are prominent drivers behind a lack of political support in fighting COVID-19 in its early stages $\left(\mathrm{R}_{\text {COVID,P,Jan }}\right)$ and Climate Change $\left(\mathrm{R}_{\text {climate, } \mathrm{P}}\right)$. Once COVID-19 prevailed closer to "home", both the effect of the imminence bias and availability heuristics worked in opposite ways and effective policy action became feasible $\left(\mathrm{R}_{\mathrm{COVID}, \mathrm{P}, \mathrm{April}}\right)$. This is not yet the case for climate change.

For enhancing public support in favour of more ambitious climate policies, policymakers are faced with two (combinable) options: They can either try to close the psychological gap between perceived and actual climate threat, moving public perception of damages $\left(\mathrm{D}_{\text {climate, }} \mathrm{P}\right)$ closer to actual climate damages $\left(\mathrm{D}_{\text {climate, }} \mathrm{A}\right)$. Alternatively, regulators can find ways to make climate policies more appealing to the public, capitalising on policy features other than their emissions reductions potential.

In order to narrow the psychological gap in public perceptions, information and awareness campaigns can be reframed to reduce the psychological distance to climate change (Jones et al. 2017). For example, campaigns can draw from advancements in attribution science to enhance the public's perceptiveness to the immediacy of climate change impacts. Attribution science substantiates the link between greenhouse gas emissions and climate change impacts, by comparing the occurrence-probability or severity of experienced or unfolding extreme weather events with the probability or severity of such events in a counterfactual climate without anthropogenic climate change (Hauser et al. 2017). Initiatives such as World Weather Attribution (2020) provide analysis rapidly in the wake of extreme weather events, demonstrating the role of climate change as people are experiencing them. Attribution studies have been cited as revealing the immediacy and concreteness of climate impacts (Osaka and Bellamy 2020). However, focus group experiments suggest that where the messaging around the link between extreme weather events and climate change is ambiguous, citizens are entrenched in pre-existing views and might resort to motivated reasoning (ibid.). This suggests that attribution science is effective in reducing the gap where there is high confidence and scientific consensus about the attributability to climate change.

For climate policy, an even bigger challenge than garnering support for climate action more generally is getting citizens on board with specific climate policies. An observation that seems consistent across different countries is that, while there are broad majorities in favour of more ambitious climate change mitigation in general, support for concrete measures is lacking (Douenne and Fabre 2020; Sommer et al. 2020). At the time of writing, this discrepancy between general support and support for specific measures seems more pronounced for climate change mitigation than for COVID-19. This might be owed to the compressed timelines of the pandemic, or tentatively indicate that public debate around specific climate mitigation strategies is more politicised.

While transparent and clear public information has been cited as an important element for successful implementation of climate policies (Atansah et al. 2017; Marshall et al. 2018), research suggests that better information alone is not sufficient for enhancing public support and that certain phenomena such as "tax aversion" are robust (Douenne and Fabre 2020). One explanation could be that "tribal politics" (Markowitz and Shariff 2012) and citizen's political worldviews play a leading role in whether specific climate change mitigation measures are able to attract majorities. In consequence, bolstering support for specific measures, and designing policy packages that can attract bipartisan support (see Lesson 4), can be an important lever for advancing on climate change mitigation. A growing body of research points to specific policy designs and communication approaches for making specific mitigation measures more appealing to the citizenry. 
For example, research on carbon pricing has highlighted the use of revenues as a key lever for public support (Carattini et al. 2019; Klenert et al. 2018a). Depending on the national context, revenues could be used for complementary green investments to provide local tangent benefits to citizens (Douenne and Fabre 2020). In addition, governments need to account for a wide variety of fairness concerns (Maestre-Andrés et al. 2019) and compensate for potentially regressive effects of climate policy (Klenert et al. 2018a, b) to enhance support.

More generally, policymakers can try to capitalize on policy features other than emissions reductions and actively highlight economic, social and health co-benefits of climate policies. For example, governments could emphasize local and tangible co-benefits such as better air quality, although evidence on the effectiveness for increasing public support is not conclusive (Bain et al. 2016; Bernauer and McGrath 2016). In addition, timing is often key when introducing policy instruments ${ }^{8}$ - climate policies need to be faded in at opportune moments, for example when fuel prices are low (Benes et al. 2015) and in careful iteration with complementary policy measures (Pahle et al. 2018).

Finally, innovative approaches in deliberative democracy seem both effective for changing people's perceptions around climate change and for bolstering support for concrete policy reforms (Howarth et al. 2020): France and the United Kingdom have very recently created citizens' assemblies on climate change to bolster public support for further climate policy reform and, in the case of France, to counter public opposition around the protests of the Yellow Vests to higher fuel prices (European Climate Foundation 2020). These assemblies have also been pushing for a green recovery from the COVID-19 crisis (Farand 2020). Anecdotal evidence from the assemblies seems to indicate that many citizen participants expressed surprise at the evidence that the impacts of climate change will be damaging to their societies (Conseil économique social et environnemental 2020; Pouliquen 2020).

\section{Lesson 3: Inequality Can Lead to Worse Outcomes}

The COVID-19 pandemic illustrates that countries are not immune to the threat of infectious disease in a manner independent to their wealth. Even if a country manages to avert a large number of cases and a full lockdown, it will still be affected by the virus indirectly, through the ensuing slump in economic activity. Similarly, while rich households have more means to protect themselves from virus exposure and often have better access to health care, their professional situations and investments may also be affected by the economic downturn. In a globalized world, domestic economic prosperity in one country is tied to economic stability in the rest of the world, as has been demonstrated by the global financial crisis.

For a number of reasons, however, the pandemic has the potential to disproportionately burden the poor (von Braun et al. 2020): low-income countries (LICs) and lower middle-income (LMICs) countries might be more vulnerable to COVID-19 as

\footnotetext{
8 Singer and Mintz-Woo (2020) point out that low fossil fuel prices as a result of the current recession present an opportune moment for introducing higher carbon prices. It may be, though, that politicians and citizens are currently even more averse to Pigouvian taxes (Kallbekken et al. 2011) than during times of stable economic growth. Burke et al. (2020) additionally note that carbon pricing revenues could be used for stimulating investment or soften fiscal deficits during the pandemic recovery.
} 
population density is higher, a greater proportion of the population suffer from preexisting health conditions, and healthcare systems are often less prepared for a pandemic (Stiglitz 2020; Bruckner and Mollerus 2020). Further, many developing and emerging economies are export-oriented, meaning that a global reduction in demand could be economically devastating (Stiglitz 2020; Bruckner and Mollerus 2020).

Within countries, it appears that the economic consequences, from both the virus itself and the measures to contain it, deepen existing inequalities even further, as already disadvantaged groups are most affected (Adams-Prassl et al. 2020; Fana et al. 2020; OECD 2020). Policymakers in countries with little informal employment made huge efforts to rapidly compensate citizens who lost their job or had to close their business temporarily due to the COVID-19 pandemic or containment measures. Apart from alleviating economic hardship, this policy also has the purpose to enhance trust in the government to ensure that people support containment measures.

In countries with large informal sectors and a constrained budget, often LICs or LMICs, such compensation policies for disadvantaged or especially affected households are more difficult to realise, but not impossible, as exemplified by the Indian state of Kerala, an internationally highly-connected region with a population above 33 million people and a GDP per capita around 2900 USD in 2018/19: by providing a community kitchen scheme and handing out basic food staples to the public, alongside other measures such as contact tracing and public information campaigns, trust in the government's confinement measures was enhanced, which curbed the spread of the virus early on (Faleiro 2020). Ensuring subsistence by providing basic income or food aid, as well as extending basic social protection to informal workers and undocumented immigrants are hence key policies to enhance support for confinement measures, particularly in low- and middle-income countries. If no such compensatory measures can be taken, governments face a Malthusian choice: Either not order a lockdown or release it too early and not contain the virus sufficiently or increase poverty and hunger. This seems to be the case in a number of developing and emerging economies at the time of writing.

Regarding climate change, there is evidence that the poor will also be disproportionately affected by the related damages (IPCC 2018; Leichenko and Silva 2014; Letta et al. 2018) while having fewer resources to adapt to a changed climate. This implies that climate change damages are likely to deepen existing inequalities even further (Ahmed et al. 2009). When this is taken into account, model simulations find that greater global mitigation efforts are optimal (Dennig et al. 2015) at least when especially affected households are not explicitly compensated for climate damages (Kornek et al. 2019). Mitigation measures, such as carbon pricing, also have the potential to affect poor households disproportionately, at least in industrialised countries (Bento 2013). Survey studies demonstrate that appropriate compensation for households that are especially affected by climate policies, for example through targeted transfers, cuts in regressive taxes or even uniform lump-sum transfers, mitigates inequalities and greatly enhances support for climate policy (Carattini et al. 2017, 2019).

A key commonality between policies that tackle COVID-19 and climate change is that restrictive mitigation policies necessitate trust between citizens and the government. The government's ability to address inequalities and the needs of especially vulnerable populations, both those created by the threat itself and those created by policy action to contain it, may be a major determinant of whether such trust will emerge. As citizens are more likely to stand behind mitigation measures that they perceive to be "fair", accounting for inequalities may further help with enhancing public support and increase the chances for successful implementation (Maestre-Andrés et al. 2019). 
A key difference between COVID-19 and climate change is the timeline: while the COVID-19 pandemic proceeds at a very high speed, climate change policy, while urgent, allows more time for planning compensatory mechanisms that are known to work even in countries with large informal sectors. In the case of climate change, recent research has demonstrated that there is no necessary trade-off between strict climate policy and inequality if policy is designed adequately (Dorband et al. 2019; Goulder et al. 2019; Klenert and Mattauch 2016; Klenert et al. 2018b; Kornek et al. 2019). We note the following specific examples for mitigation policy packages involving attempts to get to higher carbon prices with inequality as a major constraint: First, in HIC environmental tax reforms can be made progressive by recycling carbon tax revenue through transfers targeted at especially affected households, uniform lump-sum transfers or reductions in regressive taxes, as has been done at least with a part of the revenue in the Canadian province of Alberta, Switzerland and Germany, respectively (see Klenert et al. 2018a; Knopf 2019). Second, in countries with large informal sectors, there are ways to compensate citizens, given enough time for preparation, as demonstrated by the case of fossil fuel subsidy removal in India and Iran (Atansah et al. 2017). These countries relied on increasing access to banking and identification services to be able to compensate low- and middle-income households through uniform lump-sum transfers. These transfers amounted to $28 \%$ of median per-capita expenditures of a family of four in Iran in 2011, and lifted millions of households out of poverty (Atansah et al. 2017). Third, from a perspective of poverty reduction, some countries might be better off investing the proceeds of a carbon price into infrastructure: Jakob et al. (2015) and Franks et al. (2018) demonstrate that removing fossil fuel subsidies would yield sufficient funds to pay for universal access to electricity, water and sanitation for a large set of countries. Fourth, an additional benefit or carbon pricing in economies with large informal sectors is that it is more difficult to evade than labour or income taxes. In such a setting, a price on carbon could almost "pay for itself"-meaning that positive growth effects of increased government spending by a previously underfunded government could outweigh potential detrimental effects of carbon pricing_similar to a strong double dividend (Liu 2013).

Whatever shape climate policy takes in the end, it needs to take inequality into account. This is particularly true for carbon pricing and has been demonstrated by the compensatory mechanisms employed in existing pricing schemes, which in the large majority of cases include either transfers to especially affected (e.g. rural) households, uniform lump-sum transfers or cuts in regressive taxes (Carl and Fedor 2016; Klenert et al. 2018a).

\section{Lesson 4: Global Problems Necessitate (Global) Collaboration}

Historically high levels of global interconnectedness (Starnini et al. 2019) enabled SARS$\mathrm{CoV} 2$ to propagate rapidly across national borders, sparing but a few countries (Eliasaf and Tia Motwany 2020). Responses to the virus have required a global perspective. While each nation implemented its own containment measures in isolation (see Hale et al. 2020), international collaboration on vaccine development (WHO 2020b), supply line controls (Krohs et al. 2020), and knowledge sharing have been vital to supporting health and economic outcomes.

There are at least four observations on COVID-19 international collaboration that are relevant to climate change: COVID-19 has negatively affected all countries, the level of 
international collaboration has changed over the crisis, the role of multilaterals has been brought into question, and previously insurmountable political impediments have been overcome.

\subsection{A Global Crisis with Domestic Consequence}

First, COVID-19, like climate change, is a crisis that impacts all nations. High Income Countries (HICs) including the United States and the United Kingdom, have seen significant deaths (Roser et al. 2020; Lambert 2020), unemployment spikes (Kretchmer 2020), and economic contractions (IMF 2020a). For some Low- and Middle-Income Countries (LMICs) consequences also include critical food shortages (GRFC 2020) and increases in poverty (Sumner et al. 2020; Akiwumi and Valensisi 2020). Climate change is a similarly global problem - the impacts of warmer climates and increased natural disaster prevalence will be felt by all countries, and as described in Lesson 3, most acutely in LMICs (Tol et al. 2004; Mendelsohn et al. 2006; IPCC 2018; CRED and UNISDR 2018). Much of the worst impacts of COVID-19 could have been avoided by early international collaboration, for example in the form of coordinated travel restrictions against passengers departing from China (Kretchmer 2020; Schuchat in Stobbe 2020). For climate, ongoing inaction from the biggest polluters including China, the United States and India (Ritchie and Roser 2019) will increase total damages, increase recovery uncertainty and decrease accountability for other nations to set aspirational domestic targets. COVID-19 failures suggest that large polluters must act rapidly and decisively on climate action to avoid a significantly more dangerous future and difficult recovery pathway. Further, slow international responses to the virus suggest that in future global crises, nations should heed the advice of those which endure the earliest effects - for instance taking seriously the pleas of sinking Pacific island nations (Farbotko 2010).

\subsection{The Phases of International Collaboration}

International collaboration has grown over the course of the COVID-19 response. We suggest that this process is best described by four phases. First, in the early stages of the pandemic, denialism led to inadequate international responses. The World Health Organisation (WHO) was mobilised to provide international guidance in early January (WHO 2020a), but the severity of the virus was masked for a number of weeks, and nations largely ignored the threat until consequences were felt on home soil (see Hale et al. 2020).

This was followed by a second phase of response: isolationist action, in the form of border shutdowns, sudden buildout of domestic manufacturing capabilities, and rhetoric prioritising internal objectives ahead of cooperation (Gabriel 2020; Legrain 2020). For the US, uncertain international procurement pathways for medical supplies led to aggressive international competition (Bradley 2020) as well as new domestic production of ventilators (Trump 2020) and masks (Shephardson 2020). In many geographies, these actions were accompanied by increasingly hostile international relations (Thorp 2020), particularly between China and the West (Seaman 2020; Marquardt and Hansler 2020).

Most HICs have now moved to a third stage of international collaboration: knowledge and resource sharing. In some nations, notably the US and EU member states, management of medical supplies, including masks and ventilators, shifted from hoarding to sharing (Melville 2020; Myers and Rubin 2020; European Commission 2020b). In a marked development from stage two, some countries are prioritising learning from and consulting 
with other nations. For example, the Australian National Cabinet invited a foreign Head of State, New Zealand Prime Minister Jacinda Ardern, to join a Cabinet meeting for the first time in history (Department of Prime Minister and Cabinet 2020).

The fourth and final stage is full global cooperation. Once a vaccine has been developed, global supply infrastructure will need to be coordinated to ensure rapid production and dissemination (Corey et al. 2020; Peters and Greening 2020). Further, as per recent comments from Chinese leader Xi Jingping, depending on which actor develops the vaccine, it may be released as a global common good (Wheaton 2020). In this case coordination would be even more paramount to optimal delivery. Stage 4 collaboration will begin for many countries prior to widespread adoption of a vaccine, for example in establishing 'travel bubbles' between virus-free geographies (Lee et al. 2020; Whiting 2020). Australia and New Zealand are already in the process of establishing a Trans-Tasman virus-free bubble, with the possibility to include Taiwan, Vietnam and others before the end of the year, dependent on infection rates (The Economist 2020).

These four phases of international collaboration are analogous to phases of international collaboration on climate. For many nations, denialism was the modus operandi in the early 2000s, and for some it continues today. ${ }^{9}$ Many, if not most, nations operate in a state of climate isolationism, acting on climate-positive initiatives only when domestic non-climate benefits can be captured. For example, Australia has invested heavily in renewable energy supply (de Atholia et al. 2020) for economic objectives in securing cheap long-term electricity but has been a conservative actor at international climate negotiations, such as Madrid's COP25 (Morton 2019). Other countries, including many EU nations, can now be classified as stage three actors on international collaboration. These nations are binding together to encourage broad-based mutual climate action, for example through ambitious ratchets of Paris Nationally Determined Contributions (NDCs), the proposed European Green Deal of the European Commission (2019), and through green approaches to COVID-19 recovery. The fourth stage of full international cooperation is currently aspirational for all nations. It would reflect full, practical, collaboration to meet ambitious domestic targets and financially supporting LMICs to meet similarly ambitious growth-adjusted climate targets. The likelihood of meeting this scenario seems low at the time of writing, however examples such as the eradication of Smallpox (Breman and Arita 1980) demonstrate that international cooperation to end a global crisis is possible.

From COVID-19, we learn that accelerated and well-organised collaboration in global crises can be pivotally important. However, parties need to be aligned on the fundamental goals of their collaboration or risk significantly reducing the impact of their efforts. In climate, this suggests that countries already engaging in resource and information sharing should be encouraged to enhance collaboration by developing specific bilateral or regional agreements for GHG abatement and not rely only on global agreements. Exclusive membership models have been shown to be a stabilising factor and to bring superior environmental outcomes for international environmental agreements (Finus 2008; Finus and Rundshagen 2009; Nordhaus 2015). Clear emissions reductions targets and/or industryspecific emissions standards can be incentivised through the forums of existing regional institutions. For example, in 2014 the Asia-Pacific Economic Cooperation (APEC) built on 25 years of collaboration in the Asia Pacific with the Beijing Declaration, a shared plan to double renewable energy generation in the region by 2030 . The EU has enabled regional

\footnotetext{
9 Eight parties (out of 195) have not ratified the Paris Agreement on Climate Change and the United States is set to withdraw from the agreement on November 4, 2020 (Apparicio and Sauer 2020).
} 
collaboration through the Emissions Trading Scheme (ETS) (European Commission 2015), while bilateral GHG reduction agreements include those between Finland and Estonia (Government of the Republic of Finland 2004), as well as Sweden and Estonia (Government of the Republic of Estonia 2008). Every positive international agreement is important, yet to maximise impact, focus should be directed to the large emitters that do not already take the threats of climate change seriously since domestic action in these nations could have especially large spillover effects (Golombek and Hoel 2004).

\subsection{Multilaterals and Polycentric Governance}

COVID-19 has brought renewed attention to the operations of many multilateral institutions. The virus has exposed weaknesses in the WHO (Freedman 2020), culminating in a funding freeze from Washington (The White House 2020). However, at the same time, strength in the International Monetary Fund (IMF) and the United Nations Conference on Trade and Development (UNCTAD) has led to global coordination of fund raising and debt relief to enable LMICs to act for health and economic outcomes. At the time of writing, the IMF has already coordinated US\$2 bn in emergency financing and US\$0.2bn in debt relief (IMF 2020b). Regional multilaterals like the African Development Bank and Asian Development Bank also acted quickly, providing both short- and long-term relief facilities of US\$10bn and US\$20bn respectively (AfDB 2020; ADB 2020). ${ }^{10}$

On climate, the role of multilaterals has been stressed before (Bulkeley and Newell 2010; Aldy 2014; Kornek and Edenhofer 2020), particularly in directing expertise and capital to LMICs seeking simultaneous economic and climate outcomes. COVID-19 demonstrates the need for these institutions to remain apolitical in giving evidence-based advice and setting policy. In the lead up to COP26, multilateral institutions should guide constituents towards a collaborative green recovery, serving as a channel for information sharing and a platform for mutual edification. This could be achieved through a Sustainable Recovery Alliance as proposed in a recent UK government briefing (Allan et al. 2020). Such an alliance could represent a 'coalition of the willing' and "provide a forum for nations to avoid a race to the bottom, to learn from one another, and to coordinate their recovery packages for greater impact".

In parallel with advancing multilateral efforts, polycentric approaches to climate governance, tying in sub-national actors such as local and regional governments, civil society organizations and businesses, may increase local experimentation and learning, hedging against the possibility that mitigation efforts stall on the national and multilateral level (c.f. Ostrom 2010; Victor et al. 2019). COVID-19 not only showcases the importance of local and regional capacities and institutions, which were at the forefront of implementing context-appropriate responses to the pandemic (Perez and Ross 2020), but also demonstrates that polycentric governance approaches and division of political power can sometimes be a safeguard against national inaction. For example, early in the crisis, while the US federal government hesitated to implement stringent physical distancing measures, some state governors and municipal governments stepped in and compensated for an initial lack of leadership at the national level (Balz 2020). Of course, other governors did not step in,

\footnotetext{
10 Apart from coordinating cooperation on COVID-19 mitigation, such as cross-border sharing of medical supplies and hospital capacities (see European Commission 2020b), in May the European Commission decided on a $€ 750 \mathrm{bn}$ recovery plan with spending explicitly tied to sustainable goals (European Commission 2020c).
} 
illustrating that subnational action can go both ways. In climate governance, a subset of US municipal governments and businesses promised to uphold the US mitigation pledges, when the national government decided to withdraw from the Paris Agreement (World Resources Institute 2019). Bolstering regional and local governance capacities with respect to climate mitigation can make the transition more resilient to a lack of national leadership. We illustrate the potential of polycentric governance with two examples for potential strengthening mitigation efforts: first, in Canada, the EU, and others, experience with and desire for more climate action at the provincial level or member state level helps national or supranational climate policy-making respectively. Recent research in public finance considers environmental policy-making in federations as an alternative to international environmental agreements, indicating that policy can be self-enforcing and that Pareto-improving outcomes hinge on the role of the economically most important member state (Hagen and Roolfs 2019; Roolfs et al. 2020). Second, urban actors, such as those represented in part by the C40 Cities Climate Leadership Group (C40 2020), devise policy solutions against both COVID-19 and climate change, which could be upscaled to the national level. Greater representation in international climate diplomacy of such actors could advance mitigation efforts by reflecting local realities less prone to political volatility.

\subsection{Overcoming the Partisan Divide}

Willingness to impugn social freedoms in COVID-19 responses has varied across the political spectrum. Right-of-centre political actors-those who tend to support a smaller role of the state-expressed less concern about COVID-19 in the early stages of the virus (Pierre 2020; Harper et al. 2020; Rosenfeld et al. 2020) and now tend to favour accelerated removal of mobility restrictions (Brownstein 2020). Importantly, while government speed and severity of action varied across the political spectrum, once the consequences of inaction became abundantly clear, most HIC governments ultimately did introduce freedomrestricting lockdown policies for citizens. On the apparent contradiction of border closures, which were often supported more vigorously by right-of-centre actors, we interpret these as measures introduced to restrict the freedoms of outsiders as, in most cases, arrangements were made to allow citizens to return to their homes.

In climate conversations, a similar political divide has emerged in many countries (Tranter and Booth 2015; Fielding et al. 2012; Antonio and Brulle 2011) with prominent attempts to overcome it (Climate Leadership Council 2019). Again, government willingness for intervention is based on the perceived consequence of inaction, which seems to be higher for left-of-centre actors than for right-of-centre actors. This suggests that some right-of-centre individuals, regardless of income or education level, may not deem intervention to be justified until they more acutely discern the potential consequences of climate change (Zanocco et al. 2019). These conversations should be supported with reference to core conservative values including the centrality of upholding and strengthening all that is good in what has come before (see Scruton 2012; Whitmarsh and Corner 2017; Marshall et al. 2018). Climate change reflects a threat to the established social fabric of society as well as to the natural environment. Where it already exists, commentators and leaders should draw attention to successful bipartisan action as it can enable less biased reasoning and reduced polarisation (van Bavel et al. 2020). 


\section{Lesson 5: Scientific Policy Advice is Never Value-Free}

The COVID-19 pandemic has put scientific expertise into an unusual spotlight: in many countries, virologists and epidemiologists are receiving unprecedented media attention, with some reaching regular audiences in the millions through social media or podcast formats (New York Times 2020b). The scientific community has been hailed for demonstrating rapidness and a high level of international collaboration in the response to SARSCOV2 and for the development of a vaccine (Kupferschmidt 2020; New York Times 2020c). At the same time, the role of science in the decision-making around COVID-19 has also been seen as ambivalent. Epidemiologists and virologists were accused of overstepping their mandates in exerting influence on public opinion about response measures to COVID-19 (Zakaria 2020).

One complication for science-backed policy responses in light of the novel pandemic is that scientists disagree about appropriate ways to confront it. For example, this concerns the efficacy of face masks (Guardian 2020), or the role that children play in transmitting the virus, resulting in sometimes contradictory policy advice, such as regarding the reopening of schools (Mallapaty 2020).

COVID-19 has further entailed a cascade of misinformation and conspiracy theories (Grey Ellis 2020; Benson 2020), anticipated since before the pandemic (see New York Times 2019). While some of the sources of misinformation speculate about the origins of the virus or miracle cures, other sources spread doubts about the gravity of the situation and animate people to disregard government measures. Commonly, misinformation provided has the potential to put lives at risk, and the United Nations has announced an initiative to counter the current "infodemic" (UN News 2020).

In addition, the current pandemic showcases that policymakers and citizens struggle with the uncertainty surrounding preliminary scientific evidence (see Zakaria 2020; Mack et al. 2020; Manski 2019). In secondary education and the media, science is often presented as a set of irrevocable facts rather than a method of rigorous evidence-gathering to confirm or reject hypotheses in a setting of inherent uncertainty (Douglas 2017). As a result, citizens may feel disoriented when they see 'facts' change, or experts disagree. From this viewpoint, a change in epidemiological or climatic projections is easily interpreted as failure or incompetence of scientists, rather than the normal process of science in the light of new evidence (Mack et al. 2020). This may trigger fear and mistrust in science and provide fertile ground for conspiracy theories. While uncertainty surrounding the spread of the virus and likelihood of a pandemic was high initially and might in part be responsible for slow policy action in some countries, it soon decreased, which facilitated an effective policy response.

The momentum for expertise in the context of COVID-19 therefore casts new light on two questions: (1) What role should scientific advice, especially from the natural sciences, have for policy making? (2) How far should the mandate of scientific policy advisors extend?

It must be recognised that scientific expertise with relevance to public policy is always value-laden (Steele 2012; Rudner 1953; Douglas 2009). Where possible, those value judgments need to be made transparent so they can be subjected to public deliberation and democratic control. The appropriate mandate of a scientific policy advisor has to reflect both the inherent value-ladenness of scientific policy advice in general, and the specific roles and limits of expertise from different disciplines. 
We suggest that there is a difference between speaking to the efficacy and the proportionality of a measure, with consequences for the appropriate mandates for scientific policy advisors from different disciplines. To comprehend the scale, damages and likely trajectory of evolving crises like COVID-19 and climate change, empirical evidence is indispensable, be it from epidemiological and geophysical, or descriptive social science. The same is true in order to understand the potential efficacy of specific mitigation strategies. In order to make a judgment on the proportionality of a measure, in how it aligns with other societal goals, however, decision-makers cannot solely turn to epidemiologists, or geophysicists. Whenever measures entail social, economic or ethical trade-offs, their endorsement entangles more specific normative value judgments. Therefore, policymakers need to inform their choices not only by expertise from the natural sciences but should also tie in expertise from the social sciences and ethics. Depending on their specific expertise, the appropriate mandate of scientific policy advisors may sometimes be limited to speaking to the efficacy of a measure, while judgments about its proportionality require a broader consideration of different normative standpoints and public debate.

At the intersection of science and policy, the COVID-19 pandemic and climate change share several commonalities. First, similarly to COVID-19, policymakers rely on the results of scientists, especially from the natural sciences, to inform climate policy goals and discern the potential efficacy of mitigation measures. For instance, the social cost of carbon (SCC), which is a central economic measure of the damages associated with emitting one additional ton of carbon, was used to inform carbon pricing policy in the US and Canada (see Environment and Climate Change Canada 2016; Greenstone et al. 2013; US Interagency Group 2016). Second, epidemiological models and models in climate science share their reliance on assumptions and as a consequence, results have an inherent element of uncertainty. This is illustrated by the fact that results in the influential IPCC assessment are reported jointly with the corresponding degrees of uncertainty (Mastrandrea et al. 2011). Third, climate scientists are facing similar problems around misinformation, science scepticism, and science politicization as with the COVID-19 pandemic (Allgaier 2019; Farrell et al. 2019). Research suggests that ideologically motivated framing of climate change in the media and "echo chamber effects" were among the main drivers of partisan polarization over climate change in the US (Carmichael et al. 2017; Bolsen and Druckman 2018). For the US, partisanship and politicization of climate science have further been found to undermine the message of a scientific consensus on climate change (Bolsen and Druckman 2018).

Nevertheless, there is one important distinction between the evolving COVID-19 pandemic and climate change. With COVID-19 being a novel disease and the pandemic unfolding at a very high speed, scientific results are bound to be preliminary and subject to a great amount of uncertainty. Epidemiological projections need to be constantly revised in the light of new developments and new evidence. Hence, policy advice can change significantly within short timespans. This is putting decisionmakers into a highly volatile and uncertain spot. Climate change research is much more mature, with multiple iterations of improving models in light of new evidence. Further, with the IPCC reports, there is a rigorous and consolidated scientific process to evaluate the state of knowledge, which is approved by officials from each national government. Hence, the scientific consensus on climate change provides a comparatively clear and robust basis to inform climate policy. ${ }^{11}$

${ }^{11}$ The fact that climate science is more mature reduces the surrounding uncertainty to some extent and makes policy recommendations less volatile, but does not translate automatically into enhanced policy support, as additional factors, such as the psychological biases discussed in Lesson 2 outweigh the effect 
The COVID-19 pandemic showcases the importance of defining a proper role for science in the future of climate policy making. While it is widely acknowledged that policy-making should be guided by robust scientific evidence, it needs to be understood that policy decisions can never directly be drawn from data itself or be "value-neutral" (c.f. Steele 2012; Rudner 1953; Douglas 2009). Any goal setting in climate policy will require additional normative premises on how goods should be prioritised by society, and how the burden and costs of measures should be distributed.

Where does this leave the "academic qua policy advisor" for climate policy? She will need to both impartially explain the state of current research and at the same time be clear when she argues from a specific normative point of view. She should therefore neither take the role of impartially outlining coherent options to a politician, nor that of a technocrat taking decisions herself, but that of a "broker" involving the politician in a conversation about potential solutions (see Pielke Jr. 2007; Edenhofer and Kowarsch 2015; Groom and Hepburn 2017). For example, Edenhofer and Kowarsch (2015) especially stress that, in the context of environmental assessment, policy objectives are to be revised if policy means have severe side-effects. Groom and Hepburn (2017) interpret historical evidence on practical policy-making adopting economic research on discounting as strongly facilitated by charismatic policy brokers who are often (former) researchers.

A recent illustration for close collaboration between science and policy is the formulation of international mitigation objectives, such as the temperature goals in the Paris Agreement. The inclusion of the 1.5 degrees temperature goal in the Paris Agreement was seen as a success story for science-policy dialogue (Schleussner et al. 2016). The resulting special report on limiting global warming to $1.5^{\circ} \mathrm{C}$ (IPCC 2018) crucially influenced policy proposals in relation to the European Green Deal (European Commission 2019).

Finally, evidence-based strategies in science communication might be able to counter the politicization of climate science and inoculate citizens against fake news, for example by exposing misleading argumentation techniques (see Cook et al. 2017; Bolsen and Druckman 2018; Oreskes and Conway 2010; Côté and Darling 2018). The current media focus on science and researchers might also be harnessed to have positive effects on the perception of the consequences of climate change among the public. Correcting the skewed picture of "static and certain science" and creating a better understanding about the scientific process among the citizenry may increase trust in science and help fight misinformation and conspiracy theories.

\section{Conclusion}

The COVID-19 pandemic and climate change both pose major systemic risks to human prosperity, including significant externalities. The various successes and failures of COVID-19 policy responses provide a chance for reflection on climate policy and progress. We compare the shared climate change and COVID-19 policy challenges of ensuring timely action, gaining public support for mitigation policy, addressing inequality, developing international cooperation, and clearly detailing the relationship between science and

Footnote 11 (continued)

of comparatively lower uncertainty. Also, established results on climate change science and policy do not resolve uncertainty around who will bear climate damages exactly at which point in time. 


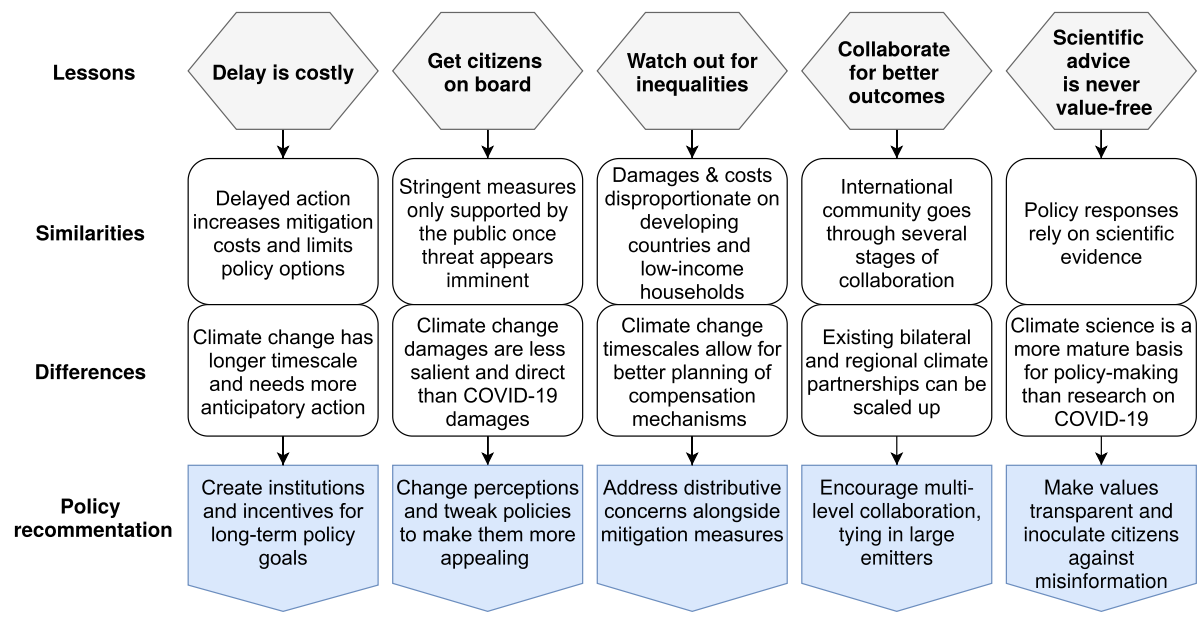

Fig. 3 Summary of similarities and differences between COVID-19 and climate change and policy lessons for climate change

policy. We confirm important parallels for good policy design (see Fig. 3): (1) delay is costly; (2) effective policies must be designed so as to overcome psychological biases; (3) policies must adequately address existing inequalities to prevent worse outcomes; (4) wide international collaboration is essential; (5) scientific policy advice needs to transparently balance factualness with inherent value judgments. Despite those parallels, we find important reasons why climate change mitigation is a harder challenge for economic policy making: it requires profound and lasting transformations of the global economy. By contrast, most measures introduced to counter the pandemic, however deep they cut right now, can be lifted once the pandemic has ended. Vital economic transformations need to be implemented long before climate change reaches catastrophic dimensions. Most of the burden of climate change damage will be borne by human beings in the future or in distant foreign locations, which makes it harder to build political priority.

The lessons we draw in this article are sufficiently broad to be applied to a multitude of global commons problems that fit certain characteristics. These are: if inadequately addressed, damages and mitigation costs rise with time; mitigation policies have the potential to create losers; these problems tend to be highly politicised. As global COVID-19 case numbers continue to rise at the time of writing, our proposed lessons are to some extent preliminary and might not apply across all country contexts.

Current political action and restrictions on personal and economic liberties are unprecedented across most generations in Western countries. The global response to the COVID-19 pandemic is a precedential case that renders arguments against immediate climate investment less compelling. A coal phase-out or a rapidly increasing carbon price, as recommended by environmental economics, has been depicted in the past by many politicians as an intolerable burden to society for which there was not enough political will. After COVID-19, we believe that it will be difficult to discard economic arguments against climate policy in this way, as the economic costs of limiting climate change to below two degrees are projected to be orders of magnitude lower than those of COVID-19 
containment measures. ${ }^{12}$ This supports proposals for immediate green recovery stimulus. Additionally, it is imperative that governance structures and institutions are bolstered in response to the pandemic, from the municipal to global level, and public perception is changed to increase the public support needed for long-term climate policies. Drawing the right lessons from this crisis will prepare policy-makers and citizens for the long-term challenges presented by climate change.

Acknowledgements We thank Alex Clark, Lucas Kruitwagen, Ryan Rafaty, Christina Roolfs, Moritz Schwarz, Rupert Stuart-Smith, Sugandha Srivastav, Johanna Wehkamp and Nigel Yau for helpful comments and Cameron Hepburn for support. We thank the Children's Investment Fund Foundation, The Downforce Trust, and the University of Oxford Social Sciences Division for support. Franziska Funke's research was supported through a pre-doctoral scholarship by the German Academic Scholarship Foundation.

\section{References}

Adams-Prassl A, Boneva T, Golin M, Rauh C (2020) Inequality in the impact of the coronavirus shock: evidence from real time surveys. IZA DP No. 13183. Retrieved on 28 April from https://www.iza.org/ publications/dp/13183

ADB (2020) ADB's comprehensive response to the COVID-19 pandemic: policy paper. Asian Development Bank, Manilla

AfDB (2020) African Development Bank Group unveils \$10 billion Response Facility to curb COVID-19. African Development Bank-building today, a better Africa tomorrow. https://www.afdb.org/en/ news-and-events/press-releases/african-development-bank-group-unveils-10-billion-response-facilitycurb-covid-19-35174. Accessed 5.19.20

Ahmed SA, Diffenbaugh NS, Hertel TW (2009) Climate volatility deepens poverty vulnerability in developing countries. Environ Res Lett 4(3):034004

Akiwumi P, Valensisi G (2020) When it rains it pours: COVID-19 exacerbates poverty risks in the poorest countries. United Nations Conference on Trade and Development (UNCTAD). https://unctad.org/en/ pages/newsdetails.aspx? OriginalVersionID=2356. Accessed 5.19.20

Aldy JE (2014) The crucial role of policy surveillance in international climate policy. Clim Change 126:279-292. https://doi.org/10.1007/s10584-014-1238-5

Allan J, Donovan C, Ekins P, Gambhir A, Hepburn C, Reay D, Robins N, Shuckburgh E (2020) A net-zero emissions economic recovery from COVID-19. Working Paper No. 20-01. Oxford Smith School of Enterprise and the Environment, Oxford

Allgaier J (2019) Science and environmental communication via online video: strategically distorted communications on climate change and climate engineering on YouTube. Front Commun 4:36

Antonio RJ, Brulle RJ (2011) The unbearable lightness of politics: climate change denial and political polarization. Sociol Q 52:195-202. https://doi.org/10.1111/j.1533-8525.2011.01199.x

Apparicio S, Sauer N (2020) Which countries have not ratified the Paris climate agreement? Climate Home News. https://www.climatechangenews.com/2020/03/01/countries-yet-ratify-paris-agreement/. Accessed 5.19.20

Atansah P, Khandan M, Moss T, Mukherjee A, Richmond J (2017) When do subsidy reforms stick? Lessons from Iran, Nigeria, and India. CGD Policy Paper. Center for Global Development, Washington

Averchenkova A, Fankhauser S, Finnegan J (2018) The role of independent bodies in climate governance: the UK's Committee on Climate Change. Grantham Research Institute on Climate Change and the Environment at the London School of Economics and Political Science. Retrieved on 12 May 2020

\footnotetext{
12 Aiming for a $\mathrm{CO}_{2}$ concentration of $450 \mathrm{ppm}$, which is compatible with limiting warming to below two degrees, would entail a reduction in the annual consumption growth rate of 0.06 percentage points (IPCC 2014 b, p. 15/16). The real reduction in the annual consumption growth rate might be well below this number, as these calculations neither account for immediate co-benefits nor for reduced climate change damages. Compared to the European Commission (2020a)'s projections of a contraction of $8 \%$ in GDP in the Euro area in 2020 due to COVID-19, the projected reduction in real annual consumption due to climate policy appears rather moderate, and is further spread out over much longer time horizons.
} 
from http://www.lse.ac.uk/GranthamInstitute/publication/role-independent-bodies-in-climate-gover nance-uk-committee-on-climate-change/. Retrieved 12 May 2020

Bain P, Milfont T, Kashima Y et al (2016) Co-benefits of addressing climate change can motivate action around the world. Nat Clim Change 6:154-157. https://doi.org/10.1038/nclimate2814

Balz D (2020) As Washington stumbled, governors stepped to the forefront. Washington Post. Retrieved on 21 May 2020 from https://www.washingtonpost.com/graphics/2020/politics/power-to-states-andgovernors-during-coronavirus/

Barbier EB (2020) Greening the post-pandemic recovery in the G20. Environ Resour Econ. https://doi. org/10.1007/s10640-020-00437-

Baron J, Ritov I (2004) Omission bias, individual differences, and normality. Organ Behav Hum Decis Process 94(2):74-85

Benes K, Cheon A, Urpelainen J, Yang J (2015) Low oil prices: an opportunity for fossil fuel subsidy reform. Center of Global Energy Policy at Columbia SIPA. https://energypolicy.columbia.edu/ research/report/low-oil-prices-opportunity-fuel-subsidy-reform. Retrieved 23 April 2020

Benson T (2020) Trolls and bots are flooding social media with disinformation encouraging states to end quarantine. Business Insider. https://www.businessinsider.com/trolls-bots-flooding-social-media -with-anti-quarantine-disinformation-2020-4?IR=T. Retrieved 12 May 2020

Bento AM (2013) Equity impacts of environmental policy. Annu Rev Resour Econ 5(1):181-196

Bernauer T, McGrath LF (2016) Simple reframing unlikely to boost public support for climate policy. Nat Clim Change 6(7):680-683

Bolsen T, Druckman JN (2018) Do partisanship and politicization undermine the impact of a scientific consensus message about climate change? Group Process Intergroup Relat 21(3):389-402

Bowles S, Carlin W (2020) The coming battle for the COVID-19 narrative. VOX CEPR Policy Portal. https://voxeu.org/article/coming-battle-covid-19-narrative. Accessed 20-06-26

Bradley J (2020) In scramble for coronavirus supplies, rich countries push poor aside. The New York Times, New York

Breman JG, Arita I (1980) The confirmation and maintenance of smallpox eradication. N Engl J Med 303(22):1263-1273. https://doi.org/10.1056/NEJM198011273032204

Brownstein R (2020) The COVID-19 crisis reveals an old divide between the parties. The Atlantic. https ://www.theatlantic.com/politics/archive/2020/03/what-covid-19-debate-has-common-aca-fight /608797/. Accessed 5.20.20

Bruckner M, Mollerus R (2020) COVID-19 and the least developed countries. UN/DESA Policy Brief \#66. https://www.un.org/development/desa/dpad/publication/un-desa-policy-brief-66-covid -19-and-the-least-developed-countries/

Bulkeley H, Newell P (2010) Governing climate change, 1st edn. Routledge, London

Burke M, Hsiang SM, Miguel E (2015) Global non-linear effect of temperature on economic production. Nature 527(7577):235-239

Burke J, Fankhauser S, Bowen A (2020) Pricing carbon during the economic recovery from the COVID19 pandemic. Grantham Research Institute on Climate Change and the Environment Policy Brief. http://www.1se.ac.uk/GranthamInstitute/publication/pricing-carbon-during-the-economic-recov ery-from-the-covid-19-pandemic/. Accessed 20-06-26

C40 (2020) "No return to business as usual": mayors pledge on COVID-19 Economic recovery.https:// www.c40.org/press_releases/taskforce-principles. Accessed 20-06-29

Carattini S, Baranzini A, Thalmann P et al (2017) Green taxes in a post-Paris world: are millions of nays inevitable? Environ Resour Econ 68:97-128. https://doi.org/10.1007/s10640-017-0133-8

Carattini S, Kallbekken S, Orlov A (2019) How to win public support for a global carbon tax. Nature 565:289-291

Carl J, Fedor D (2016) Tracking global carbon revenues: a survey of carbon taxes versus cap-and-trade in the real world. Energy Policy 96:50-77

Carmichael JT, Brulle RJ, Huxster JK (2017) The great divide: understanding the role of media and other drivers of the partisan divide in public concern over climate change in the USA, 2001-2014. Clim Change 141(4):599-612

Climate Leadership Council (2019) Economists' statement on carbon dividends. https://clcouncil.org/ economists-statement/. Accessed 6.2.20

Conseil économique social et environnemental (2020) Session \#4: Echange avec Emmanuel Macron - Convention citoyenne pour le climat. https:/www.youtube.com/watch?v=NC3gbRVz-T8. Retrieved 14 May 2020

Cook J, Lewandowsky S, Ecker UK (2017) Neutralizing misinformation through inoculation: exposing misleading argumentation techniques reduces their influence. PLoS ONE 12(5):e0175799 
Corey BL, Mascola JR, Fauci AS, Collins FS (2020) A strategic approach to COVID-19 vaccine R\&D. Science. https://doi.org/10.1126/science.abc5312

Côté IM, Darling ES (2018) Scientists on Twitter: preaching to the choir or singing from the rooftops? Facets 3(1):682-694

CRED and UNISDR (2018) Economic losses, poverty \& disasters: 1998-2017. Centre for Research on the Epidemiology of Disasters and United Nations International Strategy for Disaster, Brussels

de Atholia T, Flannigan G, Lai S (2020) Renewable energy investment in Australia. Bulletin-March Quarter 2020. Bulletin

de Langhe B, Puntoni S, Larrick R (2017) Linear thinking in a non-linear world. Harvard Bus Rev, MayJune 2017. https://hbr.org/2017/05/linear-thinking-in-a-nonlinear-world

Dennig F, Budolfson MB, Fleurbaey M, Siebert A, Socolow RH (2015) Inequality, climate impacts on the future poor, and carbon prices. Proc Natl Acad Sci 112(52):15827-15832

Department of Prime Minister and Cabinet (2020) Prime Minister Ardern attends National Cabinet. https ://www.pmc.gov.au/news-centre/domestic-policy/prime-minister-ardern-attends-national-cabinet. Accessed 5.19.20

Dietz S, Venmans F (2019) Cumulative carbon emissions and economic policy: in search of general principles. J Environ Econ Manag 96:108-129

Dorband II, Jakob M, Kalkuhl M, Steckel JC (2019) Poverty and distributional effects of carbon pricing in low-and middle-income countries-a global comparative analysis. World Dev 115:246-257

Douenne T, Fabre A (2020) Yellow Vests, Carbon Tax Aversion, and Biased Beliefs. https://halshs.archivesouvertes.fr/halshs-ffhalshs-02482639f02482639

Douglas H (2009) Science, policy, and the value-free ideal. University of Pittsburgh Pre

Douglas H (2017) Science, values, and citizens. In: Eppur si muove: doing history and philosophy of science with Peter Machamer. Springer, Cham, pp 83-96

Draulans D (2020) 'Finally, a virus got me.' Scientist who fought Ebola and HIV reflects on facing death from COVID-19. Sciencemag. https://doi.org/10.1126/science.abc7042

ECDC (2020) European Centre for Disease Prevention and Control. Outbreak of novel coronavirus disease 2019 (COVID-19): increased transmission globally—fifth update, 2 March 2020. ECDC, Stockholm. https://www.ecdc.europa.eu/sites/default/files/documents/RRA-outbreak-novel-coronavirus-disease2019-increase-transmission-globally-COVID-19.pdf

Edenhofer O, Kowarsch M (2015) Cartography of pathways: a new model for environmental policy assessments. Environ Sci Policy 51:56-64

Eliasaf B, Tia Motwany D (2020) Why 15 countries still haven't reported any cases of Covid-19. Lowy Institute. https://www.lowyinstitute.org/the-interpreter/why-15-countries-still-haven-t-reported-anycases-covid-19. Accessed 5.19.20

Engström G, Gars J, Jaakkola N, Lindahl T, Spiro D, van Benthem A (2020) What policies address both the coronavirus crisis and the climate crisis? CESifo working paper 8367

Environment and Climate Change Canada (2016) Environment and Climate Change Canada's social cost of greenhouse gas estimates. Technical Environment and Climate report, Canada. Technical update. http://policy.nl.go.kr/cmmn/FileDown.do?atchFileId=157679\&fileSn=36879

European Climate Foundation (2020) A tale of two CitIZENS' ASSEMBLies. Retrieved on 14 May from https://europeanclimate.org/a-tale-of-two-citizens-assemblies

European Commission (2015) EU ETS handbook (Handbook). European Union, Brussels. Retrieved 25 June from https://ec.europa.eu/clima/sites/clima/files/docs/ets_handbook_en.pdf

European Commission (2019) Communication from the Commission to the European Parliament, the European Council and Social Committee and the Committee of the Regions. The European Green Deal. $\operatorname{COM}(2019)$ 640. https://eur-lex.europa.eu/legal-content/EN/TXT/PDF/?uri=CELEX:52019DC064 $0 \&$ from $=\mathrm{EN}$

European Commission (2020a) European Economic Forecast Spring 2020. https://ec.europa.eu/info/sites/ info/files/economy-finance/ip125_en.pdf

European Commission (2020b) Coronavirus: European solidarity in action. Retrieved on 14 May from https ://ec.europa.eu/info/live-work-travel-eu/health/coronavirus-response/coronavirus-european-solidarity -action_en

European Commission (2020c) Europe's moment: repair and prepare for the next generation. Press release 27 May 2020. Retrieved 29 May from https://ec.europa.eu/commission/presscorner/detail/en/ ip_20_940

Faleiro S (2020) What the world can learn from Kerala about how to fight Covid-19. MIT Technology Review. https://www.technologyreview.com/2020/04/13/999313/kerala-fight-covid-19-india-coron avirus/amp/ 
Fuentes R, Galeotti M, Lanza A, Manzano B (2020) COVID-19 and climate change: a tale of two global problems. SSRN. https://doi.org/10.2139/ssrn.3604140

Fana M, Tolan S, Torrejón S, Urzi Brancati C, Fernández-Macías E (2020) The COVID confinement measures and EU labour markets. EUR 30190 EN, Publications Office of the European Union, Luxembourg. https://doi.org/10.2760/079230

Farand C (2020) Citizens' assemblies on climate change seek to shape the post-Covid recovery. Climate Change News. Retrieved on 14 May from https://www.climatechangenews.com/2020/04/17/citiz ens-assemblies-climate-change-seek-shape-post-covid-recovery/

Farbotko C (2010) Wishful sinking: disappearing islands, climate refugees and cosmopolitan experimentation. Asia Pac Viewp 51:47-60. https://doi.org/10.1111/j.1467-8373.2010.001413.x

Farrell J, McConnell K, Brulle R (2019) Evidence-based strategies to combat scientific misinformation. Nat Clim Change 9(3):191-195

Ferguson N, Laydon D, Nedjati Gilani G, Imai N, Ainslie K, Baguelin M, Bhatia S, Boonyasiri A, Cucunuba Perez ZULMA, Cuomo-Dannenburg G, Dighe A (2020) Report 9: impact of non-pharmaceutical interventions (NPIs) to reduce COVID19 mortality and healthcare demand. Imperial College. Retrieved on 21 April 2020 from https://www.imperial.ac.uk/media/imperial-college/ medicine/mrc-gida/2020-03-16-COVID19-Report-9.pdf

Fielding KS, Head BW, Laffan W, Western M, Hoegh-Guldberg O (2012) Australian politicians' beliefs about climate change: political partisanship and political ideology. Environ Polit 21:712-733. https://doi.org/10.1080/09644016.2012.698887

Finus M (2008) Game theoretic research on the design of international environmental agreements: insights, critical remarks, and future challenges. Int Rev Environ Resour Econ 2:29-67

Finus M, Rundshagen B (2009) Membership rules and stability of coalition structures in positive externality games. Soc Choice Welf 32:389-406. https://doi.org/10.1007/s00355-008-0330-Z

Flaxman S, Mishra S, Gandy A, Unwin HJT, Mellan TA, Coupland H, Whittaker C, Zhu H, Berah T, Eaton JW, Monod M (2020) Estimating the effects of non-pharmaceutical interventions on COVID-19 in Europe. Nature. https://doi.org/10.1038/s41586-020-2405-7

Franks M, Lessmann K, Jakob M, Steckel JC, Edenhofer O (2018) Mobilizing domestic resources for the Agenda 2030 via carbon pricing. Nat Sustain 1(7):350-357

Freedman L (2020) How the World Health Organisation's failure to challenge China over coronavirus cost us dearly. New Statesman

Furman J, Shadbegian R, Stock J (2015) The cost of delaying action to stem climate change: a metaanalysis. VoxEU. https://voxeu.org/article/cost-delaying-action-stem-climate-change-meta-analy sis

Gabriel S (2020) The lethal threat of COVID-19 isolationism. Project Syndicate. https://www.proje ct-syndicate.org/commentary/covid19-protectionism-undermines-europe-global-role-by-sigma r-gabriel-2020-04. Accessed 5.19.20

Gawel E, Lehmann P (2020) Killing two birds with one stone? Green dead ends and ways out of the COVID-19 crisis. Environ Resour Econ. https://doi.org/10.1007/s10640-020-00443-y

Golombek R, Hoel M (2004) Unilateral emission reductions and cross-country technology spillovers. BE J Econ Anal Policy 1:1. https://doi.org/10.2202/1538-0637.1318

Goudie AS (2018) Human impact on the natural environment [electronic resource], 8th edn. WileyBlackwell, Hoboken

Goulder LH (2020) Timing is everything: how economists can better address the urgency of stronger climate policy. Rev Environ Econ Policy 14:143-156

Goulder LH, Hafstead MA, Kim G, Long X (2019) Impacts of a carbon tax across US household income groups: what are the equity-efficiency trade-offs? J Public Econ 175:44-64

Government of the Republic of Estonia (2008) Agreement between the Government of the Republic of Estonia and the Government of the Kingdom of Sweden on Joint Implementation Projects for the Reduction of Greenhouse Gas Emissions, RT II 2008, 9, 25. Retrieved on 25/06/2020 from https:// www.riigiteataja.ee/akt/12955812

Government of the Republic of Finland (2004) Decree of the president of the Republic on the entry into force of the Act between Finland and Estonia on the enforcement of the agreement on the joint implementation of the reduction of greenhouse gas emissions and on the enforcement of provisions in the field of legislation of the agreement. Retrieved on 25/06/2020 from https://finlex.fi/fi/ sopimukset/sopsteksti/2004/20040023

Greenstone M, Kopits E, Wolverton A (2013) Developing a social cost of carbon for US regulatory analysis: a methodology and interpretation. Rev Environ Econ Policy 7(1):23-46

Grey Ellis E (2020) The coronavirus outbreak is a petri dish for conspiracy theories. Wired. Retrieved on 12 May from https://www.wired.com/story/coronavirus-conspiracy-theories/ 
GRFC (2020) Global report on food crises. World Food Programme. https://www.wfp.org/publicatio ns/2020-global-report-food-crises. Accessed 5.20.20

Groom B, Hepburn C (2017) Looking back at social discounting policy: the influence of papers, presentations, political preconditions, and personalities. Rev Environ Econ Policy 11(2):336-356

Grosjean G, Acworth W, Flachsland C, Marschinski R (2016) After monetary policy, climate policy: is delegation the key to EU ETS reform? Clim Policy 16(1):1-25

Guardian (2020) Report on face masks' effectiveness for COVID-19 divides scientists. Retrieved on 1 June 2020 from https://www.theguardian.com/world/2020/may/04/scientists-disagree-over-facemasks-effect-on-covid-19

Hagen A, Roolfs C (2019) Self-enforcing environmental federations. PET conference paper

Haidt J (2001) The emotional dog and its rational tail: a social intuitionist approach to moral judgment. Psychol Rev 108(4):814

Haidt J (2007) The new synthesis in moral psychology. Science 316(5827):998-1002

Hale T, Webster S, Petherick A, Phillips T, Kira B (2020) Oxford COVID-19 Government Response Tracker. Blavatnik School of Government. https://www.bsg.ox.ac.uk/research/research-projects/coron avirus-government-response-tracker. Accessed 5.19.20

Harper CA, Satchell LP, Fido D, Latzman RD (2020) Functional fear predicts public health compliance in the COVID-19 pandemic. Int J Ment Health Addict. https://doi.org/10.1007/s11469-020-00281-5

Hauser M, Gudmundsson L, Orth R, Jézéquel A, Haustein K, Vautard R, van Oldenborgh GJ, Wilcox L, Seneviratne SI (2017) Methods and model dependency of extreme event attribution: the 2015 European drought. Earth's Future 5(10):1034-1043

Helm D (2020) The environmental impacts of the coronavirus. Environ Resour Econ 76:21-38. https://doi. org/10.1007/s10640-020-00426-Z

Helm D, Hepburn C, Mash R (2003) Credible carbon policy. Oxf Rev Econ Policy 19(3):438-450

Hepburn C, O'Callaghan B, Stern N, Stiglitz J, Zenghelis D (2020) Will COVID-19 fiscal recovery packages accelerate or retard progress on climate change? Oxf Rev Econ Policy. https://doi.org/10.1093/ oxrep/graa015

Herrero M, Thornton P (2020) What can COVID-19 teach us about responding to climate change? Lancet Planet Health 4(5): 174

Howarth C, Bryant P, Corner A, Fankhauser S, Gouldson A, Whitmarsh L, Willis R (2020) Building a social mandate for climate action: lessons from COVID-19. Environ Resour Econ. https://doi.org/10.1007/ s10640-020-00446-9

Hsiang S, Allen D, Annan-Phan S, Bell K, Bolliger I, Chong T, Druckenmiller H, Huang LY, Hultgren A, Krasovich E, Lau P (2020) The effect of large-scale anti-contagion policies on the COVID-19 pandemic. Nature. https://doi.org/10.1038/s41586-020-2404-8

IMF (2020a) World economic outlook update, June 2020: Chapter 1. Washington, DC. Retrieved on 29 June 2020 from https://www.imf.org/en/Publications/WEO/Issues/2020/06/24/WEOUpdateJune2020

IMF (2020b) Emergency financing by region. IMF. https://www.imf.org/en/Topics/imf-and-covid19/ COVID-Lending-Tracker. Accessed 5.19.20

IPCC (2014a) Climate change 2014: impacts, adaptation, and vulnerability. Part A: global and sectoral aspects. In: Field CB, Barros VR, Dokken DJ, Mach KJ, Mastrandrea MD, Bilir TE, Chatterjee M, Ebi KL, Estrada YO, Genova RC, Girma B, Kissel ES, Levy AN, MacCracken S, Mastrandrea PR, White LL (eds) Contribution of working group II to the fifth assessment report of the intergovernmental panel on climate change. Cambridge University Press, Cambridge, United Kingdom and New York, NY, USA

IPCC (2014b) Summary for policymakers. In: Climate change 2014: mitigation of climate change. In: Edenhofer O, Pichs-Madruga R, Sokona Y, Farahani E, Kadner S, Seyboth K, Adler A, Baum I, Brunner S, Eickemeier P, Kriemann B, Savolainen J, Schlömer S, von Stechow C, Zwickel T, Minx JC (eds) Contribution of working group III to the fifth assessment report of the intergovernmental panel on climate change. Cambridge University Press, Cambridge, United Kingdom and New York, NY, USA

IPCC (2018) Global warming of $1.5^{\circ} \mathrm{C}$. An IPCC Special Report on the impacts of global warming of $1.5^{\circ} \mathrm{C}$ above pre-industrial levels and related global greenhouse gas emission pathways, in the context of strengthening the global response to the threat of climate change, sustainable development, and efforts to eradicate poverty. In: Masson-Delmotte V, Zhai P, Pörtner HO, Roberts D, Skea J, Shukla PR, Pirani A, Moufouma-Okia W, Péan C, Pidcock R, Connors S, Matthews JBR, Chen Y, Zhou X, Gomis MI, Lonnoy E, Maycock T, Tignor M, Waterfield T (eds) (in press)

Ipsos (2020) Perceived level of threat COVID-19 poses to the U.S. and individuals doubles in less than a month. Ipsos. https:/www.ipsos.com/enus/news-polls/perceived-level-of-threat-covid19-poses-doubl es 
Jakob M, Luderer G, Steckel J, Tavoni M, Monjon S (2012) Time to act now? Assessing the costs of delaying climate measures and benefits of early action. Clim Change 114(1):79-99

Jakob M, Chen C, Fuss S, Marxen A, Edenhofer O (2015) Development incentives for fossil fuel subsidy reform. Nat Clim Change 5(8):709

Johnson CK, Hitchens PL, Pandit Pranav S, Rushmore Julie, Evans Tierra Smiley, Young CCW, Doyle Megan M (2020) Global shifts in mammalian population trends reveal key predictors of virus spillover risk. Proc R Soc B 287:20192736. https://doi.org/10.1098/rspb.2019.2736

Jones C, Hine DW, Marks AD (2017) The future is now: reducing psychological distance to increase public engagement with climate change. Risk Anal 37(2):331-341

Kallbekken S, Kroll S, Cherry TL (2011) Do you not like Pigou, or do you not understand him? Tax aversion and revenue recycling in the lab. J Environ Econ Manag 62(1):53-64

Klenert D, Mattauch L (2016) How to make a carbon tax reform progressive: the role of subsistence consumption. Econ Lett 138:100-103

Klenert D, Mattauch L, Combet E, Edenhofer O, Hepburn C, Rafaty R, Stern N (2018a) Making carbon pricing work for citizens. Nat Clim Change 8(8):669-677

Klenert D, Schwerhoff G, Edenhofer O, Mattauch L (2018b) Environmental taxation, inequality and Engel's law: the double dividend of redistribution. Environ Resour Econ 71(3):605-624. https:// doi.org/10.1007/s10640-016-0070-y

Knopf B (2019) Das deutsche Klima-Finanzpaket. MCC Common Economics Blog. https://blog.mccberlin.net/post/article/das-deutsche-klima-finanzpaket.html

Kornek U, Edenhofer O (2020) The strategic dimension of financing global public goods. Eur Econ Rev. https://doi.org/10.1016/j.euroecorev.2020.103423

Kornek U, Klenert D, Edenhofer O, Fleurbaey M (2019) The social cost of carbon and inequality: when local redistribution shapes global carbon prices. CESifo working paper no. 7628

Koundouri P (2020) Never waste a good crisis: for a sustainable recovery from COVID-19. Sustainable Development Solutions Network. Retrieved on 20 April 2020 from https://www.unsdsn.org/never -waste-a-good-crisis-for-a-sustainable-recovery-from-covid-19

Kretchmer H (2020) How coronavirus has hit employment in G7 economies. World Economic Forum. https://www.weforum.org/agenda/2020/05/coronavirus-unemployment-jobs-work-impact-g7pandemic/. Accessed 5.19.20

Krohs C, Hamilton AL, Küttner M (2020) Collaboration among competitors \& COVID-19: the impact on EU and national case laws. e-Compet Bull. Retrieved April 9, 2020, from, https://www.concu rrences.com/en/bulletin/special-issues/competition-law-covid-19-en/collaboration-among-compe titors-covid-19-the-impact-on-eu-and-national-case-en

Kupferschmidt K (2020) A completely new culture of doing research. Coronavirus outbreak changes how scientists communicate. Science Magazine. Retrieved May 12, 2020, from, https://www.scien cemag.org/news/2020/02/completely-new-culture-doing-research-coronavirus-outbreak-changeshowscientists

Lahcen B, Brusselaers J, Vrancken K, Dams Y, Da Silva Paes C, Eyckmans J, Rousseau S (2020) Green recovery policies for the COVID-19 crisis: modelling the Impact on the economy and greenhouse gas emissions. Environ Resour Econ. https://doi.org/10.1007/s10640-020-00454-9

Lambert L (2020) The coronavirus has now killed more Americans than the Vietnam War, Gulf War, Afghanistan War, and Iraq War combined. Fortune. https://fortune.com/2020/05/15/coronaviru s-deaths-us-covid-19-death-rate-covid-19-more-than-korean-vietnam-gulf-afghanistan-iraq-warscombined/. Accessed 5.19.20

Le Quéré C, Jackson RB, Jones MW et al (2020) Temporary reduction in daily global $\mathrm{CO}_{2}$ emissions during the COVID-19 forced confinement. Nat Clim Chang. https://doi.org/10.1038/s4155 8-020-0797-x

Lee K, Worsnop CZ, Grépin KA, Kamradt-Scott A (2020) Global coordination on cross-border travel and trade measures crucial to COVID-19 response. Lancet. https://doi.org/10.1016/S0140 $-6736(20) 31032-1$

Legrain P (2020) The coronavirus is killing globalization and empowering nationalists and protectionists. Foreign Policy. Retrieved May 19, 2020, from, https://foreignpolicy.com/2020/03/12/coron avirus-killing-globalization-nationalism-protectionism-trump/

Leichenko R, Silva JA (2014) Climate change and poverty: vulnerability, impacts, and alleviation strategies. Wiley Interdiscip Rev Clim Change 5(4):539-556

Lenton TM (2020) Tipping positive change. Philos Trans R Soc B 375(1794):20190123

Letta M, Montalbano P, Tol RS (2018) Temperature shocks, short-term growth and poverty thresholds: evidence from rural Tanzania. World Dev 112:13-32

Levy MR, Tasoff J (2017) Exponential-growth bias and overconfidence. J Econ Psychol 58:1-14 
Liu AA (2013) Tax evasion and optimal environmental taxes. J Environ Econ Manag 66(3):656-670

Mack K, Kruszelnicki K, Randall L et al (2020) Reaching out. Nat Rev Phys. https://doi.org/10.1038/s4225 4-020-0185-5

Maestre-Andrés S, Drews S, van den Bergh J (2019) Perceived fairness and public acceptability of carbon pricing: a review of the literature. Clim Policy 19(9):1186-1204

Mallapaty S (2020) How do children spread the coronavirus? The science still isn't clear. Nature News. https://www.nature.com/articles/d41586-020-01354-0

Manski CF (2019) Communicating uncertainty in policy analysis. Proc Natl Acad Sci 116(16):7634-7641

Markowitz EM, Shariff AF (2012) Climate change and moral judgement. Nat Clim Change 2(4):243-247

Marquardt A, Hansler J (2020) US push to include "Wuhan virus" language in G7 joint statement fractures alliance. CNN. https://www.cnn.com/2020/03/25/politics/g7-coronavirus-statement/index.html. Accessed 5.19.20

Marshall G, Conway D, Webster R, Comeau L, Besley DJ, Saldarriaga Arango I (2018) Guide to communicating carbon pricing (English). World Bank Group, Washington. Retrieved on 23 April 2020 from http://documents. worldbank.org/curated/en/668481543351717355/Guide-to-Communicating-Carbo n-Pricing

Mastrandrea MD, Mach KJ, Plattner GK, Edenhofer O, Stocker TF, Field CB, Ebi KL, Matschoss PR (2011) The IPCC AR5 guidance note on consistent treatment of uncertainties: a common approach across the working groups. Clim Change 108(4):675

Melville J (2020) Isolationism is not the way forward during coronavirus. https://www.aljazeera.com/indep th/opinion/isolationism-coronavirus-200406074443291.html. Accessed 5.19.20

Mendelsohn R, Dinar A, Williams L (2006) The distributional impact of climate change on rich and poor countries. Environ Dev Econ 11:159-178. https://doi.org/10.1017/S1355770X05002755

Morton AM (2019) UN climate talks: Australia accused of "cheating" and thwarting global deal. The Guardian

Myers SL, Rubin AJ (2020) Its Coronavirus cases dwindling, China turns focus outward. New York Times. Retrieved from https:/www.nytimes.com/2020/03/18/world/asia/coronavirus-china-aid.html

New York Times (2019) We must prepare for the next pandemic: we'll have to battle both the disease and the fake news. Retrieved on 8 May 2020 from https://www.nytimes.com/2019/06/17/opinion/pande mic-fake-news.html

New York Times (2020a) Trump urges limits amid pandemic, but stops short of national mandates. Retrieved on 21 April 2020 from https://www.nytimes.com/2020/03/16/us/politics/trump-coronaviru s-guidelines.html

New York Times (2020b) The rising heroes of the coronavirus era? Nations' top scientists. Retrieved on 12 May 2020 from https://www.nytimes.com/2020/04/05/world/europe/scientists-coronavirus-heroe s.html

New York Times (2020c) Covid-19 changed how the world does science, together. Retrieved on 12 May 2020 from https://www.nytimes.com/2020/04/01/world/europe/coronavirus-science-research-coope ration.html

Nordhaus W (2015) Climate clubs: overcoming free-riding in international climate policy. Am Econ Rev 105(4):1339-1370

OECD (2020) COVID-19: protecting people and societies. Retrieved on 13 May 2020 from http://www. oecd.org/inclusive-growth/resources/COVID-19-Protecting-people-and-societies.pdf

Oreskes N, Conway EM (2010) Defeating the merchants of doubt. Nature 465(7299):686-687

Osaka S, Bellamy R (2020) Natural variability or climate change? Stakeholder and citizen perceptions of extreme event attribution. Glob Environ Change 62:102070

Ostrom E (2010) Beyond markets and states: polycentric governance of complex economic systems. Am Econ Rev 100(3):641-672

Pahle M, Burtraw D, Flachsland C, Kelsey N, Biber E, Meckling J, Edenhofer O, Zysman J (2018) Sequencing to ratchet up climate policy stringency. Nat Clim Change 8(10):861-867

Pei S, Kandula S, Shaman J (2020) Differential effects of intervention timing on COVID-19 spread in the United States. MedRxiv. https://doi.org/10.1101/2020.05.15.20103655

Perez V, Ross JM (2020) Federalism and polycentric government in a pandemic. Special edition policy brief. Mercatus Center at George Mason University

Peters T, Greening P (2020) How do we prepare for COVID-19 vaccine delivery? https://www.birmingham .ac.uk/news/thebirminghambrief/items/2020/05/How-do-we-prepare-for-covid-19-vaccine-delivery. aspx. Accessed 5.19.20

Pielke RA Jr (2007) The honest broker: making sense of science in policy and politics. Cambridge University Press, Cambridge 
Pierre J (2020) Disregarding science: the politics of COVID-19 beliefs. Psychology Today. https://www. psychologytoday.com/blog/psych-unseen/202003/disregarding-science-the-politics-covid-19-belie fs. Accessed 5.20.20

Pouliquen F (2020).Climat : La convention citoyenne a-t-elle changé les convictions de ses 150 membres? 20 minutes. Retrieved on 12 May 2020 from https://www.20minutes.fr/planete/27145 51-20200209-climat-convention-citoyenne-change-convictions-150-membres

Pueyo T (2020) Coronavirus: why you must act now. Medium. Retrieved on 21 April 2020 from https:// medium.com/@ tomaspueyo/coronavirus-act-today-or-people-will-die-f4d3d9cd99ca

Ritchie H, Roser M (2019) $\mathrm{CO}_{2}$ and greenhouse gas emissions. Our World in Data

Roolfs C, Gaitan B, Edenhofer O (2020) Make or brake-rich states in voluntary federal emission pricing. SSRN Working Paper http://dx.doi.org/10.2139/ssrn.2941505

Rosenbloom D, Markard J (2020) A COVID-19 recovery for climate. Science 368(6490):447

Rosenfeld DL, Rothgerber H, Wilson T (2020) Politicizing the COVID-19 pandemic: ideological differences in adherence to social distancing (preprint). https://doi.org/10.31234/osf.io/k23cv

Roser M, Ritchie H, Ortiz-Ospina E, Hasell J (2020) Coronavirus pandemic (COVID-19). Our World in Data

Rudner R (1953) The scientist qua scientist makes value judgments. Philos Sci 20(1):1-6

Schleussner CF, Rogelj J, Schaeffer M, Lissner T, Licker R, Fischer EM, Frieler K, Hare W (2016) Science and policy characteristics of the Paris Agreement temperature goal. Nat Clim Change 6(9):827-835

Scruton R (2012) Green philosophy: how to think seriously about the planet [electronic resource], Ebook central. Atlantic Books Ltd.

Seaman J (2020) COVID-19 and Europe-China relations: a country-level analysis

Settele J, Díaz S, Brondizio E, Daszak P (2020) Stimulus measures must save lives, protect livelihoods, and safeguard nature to reduce the risk of future pandemics. Intergovernmental Science-Policy Platform on Biodiversity and Ecosystem Services (IPBES) Expert Guest Article on 27 April 2020 COVID-19. https://ipbes.net/sites/default/files/2020-04/COVID19\%20Stimulus\%20IPBES\%20 Guest\%20Article_English.pdf

Shephardson D (2020) Pentagon awarding contract to boost N95 mask production capacity by 39 million. Reuters, London

Singer P, Mintz-Woo K (2020) Put a price on carbon now! Project Syndicate. Retrieve on 20 May from https ://www.project-syndicate.org/commentary/low-oil-prices-ideal-time-for-carbon-tax-by-peter-singe r-and-kian-mintz-woo-2020-05

Sommer S, Mattauch, L, Pahle M (2020) Supporting carbon taxes and the role of fairness (in preparation)

Starnini M, Boguná M, Serrano MÁ (2019) The interconnected wealth of nations: shock propagation on global trade-investment multiplex networks. Sci Rep 9:13079. https://doi.org/10.1038/s4159 8-019-49173-2

Steele K (2012) The scientist qua policy advisor makes value judgments. Philos Sci 79(5):893-904

Stiglitz JE (2020) Internationalizing the crisis. Project Syndicate. Retrieved on 22 April 2020 from https ://www.project-syndicate.org/commentary/covid19-impact-on-developing-emerging-economiesby-joseph-e-stiglitz-2020-04

Stobbe (2020) Health official says US missed some chances to slow virus. Associated Press News. https ://apnews.com/a758f05f337736e93dd0c280deff9b10. Accessed 5.19.20

Sumner A, Hoy C, Ortiz-Juarez E (2020) Estimates of the impact of COVID-19 on global poverty. UNUWIDER. https://www.wider.unu.edu/publication/estimates-impact-covid-19-global-poverty. Accessed 5.19 .20

Sunstein C (1997) Bad deaths. J Risk Uncertain 14(3):259-282

The Economist (2020) Could travel bubbles offer a route to economic recovery?. The Economist, London

The White House (2020) President Donald J. Trump is demanding accountability from the World Health Organization. The White House. https://www.whitehouse.gov/briefings-statements/president-donal d-j-trump-demanding-accountability-world-health-organization/. Accessed 5.19.20

Thorp HH (2020) Why WHO? Science. https://doi.org/10.1126/science.abc3400

Tol RSJ, Downing TE, Kuik OJ, Smith JB (2004) Distributional aspects of climate change impacts. Glob Environ Change Benefits Clim Policy 14:259-272. https://doi.org/10.1016/j.gloenvcha.2004.04.007

Tranter B, Booth K (2015) Scepticism in a changing climate: a cross-national study. Glob Environ Change 33:154-164. https://doi.org/10.1016/j.gloenvcha.2015.05.003

Trump D (2020) Memorandum on order under the defense production act regarding the purchase of ventilators. Retrieved May 19, 2020, from, https://www.whitehouse.gov/presidential-actions/memorandum -order-defense-production-act-regarding-purchase-ventilators/ 
Tversky A, Kahneman D (1973) Availability: a heuristic for judging frequency and probability. Cogn Psychol 5:207-232

Tversky A, Kahneman D (1974) Judgement under uncertainty: heuristics and biases. Science 185:1124-1131

UN News (2020) UN tackles 'infodemic' of misinformation and cybercrime in COVID-19 crisis. Retrieved on 8 May 2020 from https://www.un.org/en/un-coronavirus-communications-team/un-tackling$\% \mathrm{E} 2 \% 80 \% 98$ infodemic\%E2\%80\%99-misinformation-and-cybercrime-covid-19

US Interagency Group (2016) Interagency working group on social cost of carbon: Technical update of the social cost of carbon for regulatory impact analysis under executive order 12866. Technical report, United States Government. Retrieved on 29 June from: https://19january2017snapshot.epa.gov/sites/ production/files/201612/documents/sc_co2_tsd_august_2016.pdf

van Bavel JJ, Baicker K, Boggio PS, Capraro V, Cichocka A, Cikara M, Crockett MJ, Crum AJ, Douglas KM, Druckman JN, Drury J, Dube O, Ellemers N, Finkel EJ, Fowler JH, Gelfand M, Han S, Haslam SA, Jetten J, Kitayama S, Mobbs D, Napper LE, Packer DJ, Pennycook G, Peters E, Petty RE, Rand DG, Reicher SD, Schnall S, Shariff A, Skitka LJ, Smith SS, Sunstein CR, Tabri N, Tucker JA, van der Linden S, van Lange P, Weeden KA, Wohl MJA, Zaki J, Zion SR, Willer R (2020) Using social and behavioural science to support COVID-19 pandemic response. Nat Hum Behav 4:460-471. https:// doi.org/10.1038/s41562-020-0884-z

Victor D, Geels F, Sharpe S (2019) Accelerating the low carbon transition: the case for stronger, more targeted and coordinated international action. Brookings, London

von Braun J, Zamagni S, Sánchez Sorondo M (2020) The moment to see the poor. Science 368(6488):214. https://doi.org/10.1126/science.abc2255

Wang CJ, Ng CY, Brook RH (2020) Response to COVID-19 in Taiwan: big data analytics, new technology, and proactive testing. JAMA 323(14):1341-1342. https://doi.org/10.1001/jama.2020.3151

Wheaton S (2020) Chinese vaccine would be 'global public good,' Xi says. Politico. https://www.politico. com/news/2020/05/18/chinese-vaccine-would-be-global-public-good-xi-says-265039. Accessed 5.19 .20

Whiting K (2020) These countries are making 'travel bubbles' for post-lockdown tourism. World Economic Forum. https://www.weforum.org/agenda/2020/05/tourism-coronavirus-travel-bubble-lockdown/. Accessed 5.19.20

Whitmarsh L, Corner A (2017) Tools for a new climate conversation: a mixed-methods study of language for public engagement across the political spectrum. Glob Environ Change 42:122-135

WHO (2020a) World Health Organisation Timeline-COVID-19. https://www.who.int/news-room/detai 1/27-04-2020-who-timeline-covid-19. Accessed 5.18.20

WHO (2020b) Public statement for collaboration on COVID-19 vaccine development. Public statement for collaboration on COVID-19 vaccine development. https://www.who.int/news-room/detail/13-042020-public-statement-for-collaboration-on-covid-19-vaccine-development. Accessed 5.19.20

World Resources Institute (2019) Accelerating America's pledge: how U.S. States, cities and businesses can deliver ambitious climate action. Retrieved on 21 April 2020 from https://www.wri.org/blog/2019/12/ accelerating-americas-pledge-how-us-states-cities-and-businesses-can-deliver-ambitious

World Weather Attribution (2020) https://www.worldweatherattribution.org/

Zakaria F (2020) The pandemic is too important to be left to the scientists. Washington Post. Retrieved on 5 May 2020 from https://www.washingtonpost.com/opinions/itll-take-more-than-just-scientists-tostem-this-pandemic/2020/04/30/9ee1daf6-8b1d-11ea-9dfd-990f9dcc71fc_story.html

Zanocco C, Boudet H, Nilson R, Flora J (2019) Personal harm and support for climate change mitigation policies: evidence from 10 US communities impacted by extreme weather. Glob Environ Change 59:101984. https://doi.org/10.1016/j.gloenvcha.2019.101984

Publisher's Note Springer Nature remains neutral with regard to jurisdictional claims in published maps and institutional affiliations. 